http://kitaibelia.unideb.hu/

ISSN 2064-4507 (Online) • ISSN 1219-9672 (Print)

(C) 2015, Department of Botany, University of Debrecen, Hungary

20 (2): 213-234.; 2015

DOI: $10.17542 /$ kit.20.213

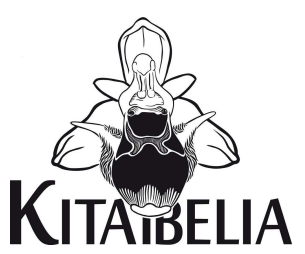

\title{
Kiegészítések a Nyugat-Dunántúl flórájának ismeretéhez
}

\author{
MEsTERHÁZY Attila ${ }^{1} \&$ KULCSÁR László ${ }^{2}$
}

(1) H-9500 Celldömölk, Hunyadi u. 55.; amesterhazy@gmail.com

(2) H-9600 Sárvár, Orsolya u. 19.

\section{Contributions to the flora of Western-Transdanubia (W Hungary)}

\begin{abstract}
In this paper, we presented the results of our floristic survey in West-Hungarian region. The data were collected between 2005 and 2015 and supportted with herbaria or photo-documentation. This paper reports new floristic data of 98 taxa from West-Hungary with altogether 172 field-collected data records. In the survey we focused on little-known taxa with a phyto-geographic importance. For some taxa we checked the herbarium specimens of Savaria Museum and Natural History Museum of Budapest. During our fieldwork we recorded 8 species new to W-Hungary, including 3 species considered to be native to the region [Oenanthe banatica Heuff., Koeleria pyramidata (Lam.) P. Beauv., Polycnemum majus A. Braun.]. Almost all of the recorded species are regarded as indigenous plants, many of them has nature conservation importance, thus, their monitoring are highly advised. We found new localities of many species which of high importance for plant geography describing their current distribution. Most of the recorded species occur in natural or semi-natural habitats, but some taxa were found in synanthropic habitats and extensive arable lands.
\end{abstract}

Keywords: adventive species, distribution, floristic data, vascular flora, West-Hungary

Összefoglalás - Cikkünkben az elmúlt közel 10 évben a Nyugat-Dunántúlon végzett florisztikai kutatásaink eredményeit ősszegezzük. Munkánkban törekedtünk a Nyugat-Dunántúl területén előforduló ritka, kevés irodalmi adattal rendelkező vagy növényföldrajzi szempontból érdekesebb taxonok adatainak közlésére. A cikkben szereplő enumeráció 98 taxon 172 előfordulási adatát közli. A kutatás során előkerült a Nyugat-Dunántúl flórájára nézve 9 új faj, melyek közül 3 faj tekinthető őshonosnak [Oenanthe banatica Heuff., Koeleria pyramidata (Lam.) P.Beauv., Polycnemum majus A. Braun.], míg 6 faj valószínúleg adventív megtelepedés eredménye [Artemisia annua L., Fallopia sachalinensis (F. Schmidt) Ronse Decr., Rumex pulcher L., Cerasus vulgaris Mill. subsp. acida (Dumort.) Dostál, Salvia austriaca Jacq., Digitalis lanata Ehrh.]. A cikkben szereplő további taxonok döntően őshonos növények, többségük védett vagy természetvédelmi szempontból kiemelt jelentőségű, ezért monitorozásuk javasolt. Több, a régióban még ritka adventív faj lelőhelyét ismertetjük (például Calepina irregularis Adans.). Számos, növényföldrajzi szempontból jelentős fajról közlünk adatokat, elősegítve ezzel elterjedésük pontosabb megismerését. Az ismertetésre kerülő taxonok leginkább természetes vagy féltermészetes élőhelyeken fordulnak elő, de néhány ritka, extenzív szántókhoz vagy szünantróp élőhelyekhez köthető ritka gyom [például Coronopus squamatus (Forssk.) Asch., Thesium dollineri Murb.] előfordulásáról is beszámolunk.

Kulcsszavak: adventív fajok, edényes flóra, elterjedés, florisztikai adatok, Nyugat-Magyarország 


\section{Bevezetés}

A Nyugat-Dunántúl az 1960-as évek végéig a florisztikai és növényföldrajzi kutatások egyik fontos színtere volt. Publikációk egész sora látott napvilágot a kutatási eredmények felhasználásával. Az 1970-es években már úgy tűnt, hogy nincs további vizsgálandó feladat a térségben, holott a Nyugat-Dunántúl földrajzi nagytáj területének csupán egyes részeiről (Soproni-hegység, Kőszegi-hegység, Őrség) készültek részletesebb felmérések, míg a botanikailag kevésbé frekventáltabb területekről (például Sopron-Vasi-sík, Kemeneshát) csupán szórványos adatok bukkantak elő. Közel harminc év szünet után az 1990-es évek végén új lendületet vett terepbotanikai kutatások újra felfedezték a Nyugat-Dunántúl botanikai értékeit. Elsősorban a II. világháború után elzárt határmenti területek kutatása indult meg újult erővel, amely így ismét a már korábban kutatott területek botanikai vizsgálatát eredményezte. Ezek a felmérések természetesen fontos információkat szolgáltattak a térségben az elmúlt 50-60 évben bekövetkezett változásokról, azonban a korábban nem kutatott területek továbbra is háttérbe szorultak. A több mint hatvan éve kialakított növényföldrajzi határokat (JEANPLONG 1956) ezek az új vizsgálatok lényegesen nem módosították.

A Nyugat-Dunántúl florisztikai kutatásának illetve növényföldrajzi kérdéseinek újragondolását KIRÁLY et al. (2007) vetették fel. Tanulmányukban részletesen kitérnek arra, hogy a Nyugat-Dunántúlon mind a földrajzi kistáj beosztás, mind a növényföldrajzi beosztás tekintetében számos pontatlanság és anomália lelhető fel. KIRÁLY et al. (2007) megállapításaival egyetértünk, és úgy gondoljuk, hogy a Nyugat-Dunántúlon sem a florisztikai kutatásokat sem a növényföldrajzi kérdéseket nem lehet lezártnak tekintetni. A florisztikai növényföldrajz kérdéseit csak további terepbotanikai vizsgálatokkal lehet tisztázni. A terepi vizsgálatokat a még kevésbé kutatott kistájakra is ki kell terjeszteni.

\section{Anyag és módszer}

Jelen tanulmányban az elmúlt közel 10 évben végzett terepbejárások adatait gyűjtöttük öszsze. Munkánkban törekedtünk a Nyugat-Dunántúl területén előforduló ritka, kevés irodalmi adattal rendelkező vagy növényföldrajzi szempontból érdekesebb taxonok adatainak közlésére. Az egyes kistájak vonatkozásában az új előfordulásokat is jelezzük. A cikkben szereplő taxonok esetében herbáriumi anyag (Savaria Múzeum [SAMU], Magyar Természettudományi Múzeum Növénytára [BP]) is átvizsgálásra került. A hivatkozott herbáriumi adatoknál a példányok sorszámát is feltüntetjük.

Az adatok ismertetése KIRÁLY et al. (2007) módszerét követi, ezért jelen közlemény a hivatkozott tanulmány kiegészítésének is tekinthető.

A taxonok felsorolása az Új Magyar Füvészkönyvben (KIRÁly 2009) szereplő sorszámozást követi, ahogy a taxonok elnevezése tekintetében is ezt a munkát tekintettük irányadónak. A lelőhelyek ismertetése a községhatár megadásával, valamint a lelőhely földrajzi kistáj szerinti besorolásával történik (DövÉNYI 2010). Ezen kívül a helyi földrajzi név ismertetése mellett az élőhelyre utaló adatot és szögletes zárójelben a magyarországi flóratérképezés kvadrátazonosítóját (KIRÁLY 2003) is feltüntetjük.

\section{Alkalmazott rövidítések:}

Tájföldrajzi kistájak:

AKH - Alsó-Kemeneshát; AZV - Alsó-Zala-völgy; ELD - Egerszeg-Letenyei-dombság; FKH Felső-Kemeneshát; Fô - Felső-Őrség; FZV - Felső-Zala-völgy; GYS - Gyöngyös-sík; KZD (G) - 
Közép-Zalai-dombság (Göcsej); KV - Kerka-vidék (Hetés); MBS - Mura-balparti sík; NYBS Nyugat-Belső-Somogy; PS - Pinka-sík; PV - Principális-völgy; RV - Rába-völgy; RTS - Rábai teraszos sík; RS - Répce-sík; SM - Soproni-medence; ZH - Zalaapáti-hát; VH - Vas-hegy és Kőszeghegyalja; VHH - Vasi Hegyhát

\section{Adatközlők:}

GÁ: Gruber Ágnes; FS: Farkas Sándor; KB: Keszei Balázs; KG: Király Gergely; KL: Kulcsár László; LA: Lelkes András; MA: Mesterházy Attila; ÓM: Óvári Miklós; SD: Schmidt Dávid; SZ: Schubert Zoltán; SZZS: Szekeres Zsófia

\section{Eredmények}

Az enumerációban összesen 98 taxonról közlünk adatokat a térségből, melyek mindegyikét herbáriumi példánnyal vagy fotóval dokumentáltuk. A Nyugat-Dunántúl flórájára a kutatás során előkerült új fajok száma 9, melyek közül 3 faj [Oenanthe banatica Heuff., Koeleria pyramidata (Lam.) P.Beauv., Polycnemum majus A. Braun.] tekinthető őshonosnak. Ezek közül az Oenanthe banatica és a Koeleria pyramidata az egész Dunántúlon ritka fajnak számít. Utóbbinak a most közölt előfordulás a második hazai adata. A fennmaradó 6 faj alkalmi megtelepedésű adventív [Artemisia annua L., Fallopia sachalinensis (F. Schmidt) Ronse Decr., Rumex pulcher L., Cerasus vulgaris Mill. subsp. acida (Dumort.) Dostál, Salvia austriaca Jacq., Digitalis lanata Ehrh.], melyek közül a legjelentősebbnek a Fallopia sachalinensis számít, hisz ennek a fajnak csak egy hiteles hazai adata ismert.

Az adatok jelentős része a régióban őshonos, de ritka fajok elterjedéséhez ad új információkat, valamint egyes nehezen határozható, ennél fogva hiányosan ismert fajok új előfordulásait ismerteti, néhány esetben taxonómiai kritikák megfogalmazásával. A taxonok leginkább természetes vagy féltermészetes élőhelyeken fordulnak elő, de néhány ritka, extenzív szántókhoz vagy szünantróp élőhelyekhez köthető gyom előfordulásáról is közlünk adatokat. Számos faj a Kisalföldön gyakoribbnak számít, régiónkban történő előfordulásaiknak leginkább növényföldrajzi jelentősége van [például Cardamine parviflora L., Cirsium brachycephalum Jur., Coronopus squamatus (Forssk.) Asch., Dipsacus pilosus L., Hesperis tristis L.). Más fajok (Blechnum spicant (L.) Roth., Carex randalpina B. Wallnöfer, C. cespitosa L., Dactylorhiza fuchsii (Druce) Soó] növényföldrajzi jelentőségét az adja, hogy az Alpok magasabb régióiban fordulnak elő, és alacsonyabb tengerszint feletti magasságban csak rendkívül ritkán jelennek meg. Az enumerációban megtalálható néhány szubatlantikus elterjedésű faj is [például Crepis taraxacifolia Thuill, Teesdalia nudicauilis (L.) R. Br., Veronica dillenii Crantz.], melyek döntően Dél-Zalában fordulnak elő. Adataink számos védett növényről szolgáltatnak információkat, ezzel segítve a térségben zajló természetvédelmi munkákat. Különös figyelmet érdemelnek a korábbi hagyományos gazdálkodáshoz kötődő fajok [Pulmonaria angustifolia L., Carex fritschii Waisb., Pulicaria vulgaris Gaertn.], melyek a tájhasználat megváltozásával az utóbbi évtizedekben megritkultak, ezért állományaikat érdemes figyelemmel kísérni.

\section{Enumeráció}

12. Equisetum fluviatile L. em. Ehrh. - FKH: Szőce, legeltetett láprét szivárgóvizes részén [9165.1] (MA 2010); Hegyhátszentjakab, a Vadása-tó déli partszegélyében [9165.1] (SZ 2013). - Korábban a Rábától délre számos helyről jelezték (KÁROLYI \& Pócs 1968, JEANPLONG 1999), azonban ezeket az előfordulásokat a jelen munkában közölt adatok kivételével aktuálisan nem sikerült megerősíteni. A szőcei láprétről korábban KÁRoLYI \& Pócs (1968) említette, de ezt később nem erősítették meg annak ellenére, hogy a botanikai kutatások 
szempontjából frekventált helyről van szó. A most ismertetésre kerülő szőcei előfordulás egy erősen legeltetett lápréten található, mely korábban egy kezeletlen magassásos, nádas volt. A faj újbóli megjelenése a rét legeltetésének köszönhető és feltételezhető, hogy a régebbi ismert állományok eltűnése is annak tudható be, hogy a nedves réteken napjainkban ezt a kezelést már - gyakran természetvédelmi indokból - nem végzik, és így számos pionír faj - köztük az iszapzsurló - kiszorul az élőhelyről.

17. Ophioglossum vulgatum L. - Fô: Rönök, a felsőrönöki vízmű melletti hegyi réten több száz töves állomány [9064.1] (SZ 2007); Nemesmedves, „Magyar-hegy” keleti lejtőjén, hegyi réten kb. 30 tő [9064.1] (SZ 2008). - A Felső-Őrség területéről eddig még nem közölték. A Rábától délre több régi adata és aktuális előfordulása is ismert (KÁROLYI \& PóCS 1968, KIRÁLY et al. 2002, BODONCZI 2002). A Nyugat-Dunántúl északi részén viszont csak a Kőszegi-hegységből (Cák) (KIRÁLY 1996), illetve a Soproni-hegységből (Harka, Arbesz-rét) (KIRÁLY 2004) van adata.

50. Polystichum setiferum (Forssk.) Woyn. - AKH: Bejcgyertyános, Farkas-erdő telepített duglász fenyvesében néhány tő [8867.2] (KL 2011). Fố: Kemestaródfa, a Strém-patak partján, meredek északi letörés alján 1 jól fejlett tő [9064.2] (SZ 2005). - A faj a térségünkben a $P$. aculeuatum-nál sokkal ritkább. Irodalmi adatok szerint az Őrségben Ivánc (JEANPLONG 1972), az Alsó-Kemenesháton Káld illetve Ostffyasszonyfa környékén fordult elő (HORVÁTH \& JEANPLONG 1962). Aktuális adatait a Zalai-dombság területéről (FARKAS 1999), a Vendvidékről, az Őrségből (BoDONCZI 2002), valamint a Sopronihegységből (KIRÁLY 2004) ismerjük, azonban mindenhol csak kis egyedszámú (1-2 töves) állománya fordul elő.

51. Polystichum aculeatum (L.) Roth. - AKH: Bejcgyertyános, Farkas-erdő telepített duglász fenyvesében [8867.2] (KL 2011); Sárvár, Városi-erdő telepített akácos útrézsűjében [8767.4] (KL 2015). RV: Nádasd, a Csörnöc partján égerliget alatt egy régi földkupac oldalában 1 tő [9065.2] (SZ 2012); Halogy, a Rába és a Berki-patak között, rezgőnyárral benőtt vizesárok partján 1 tő [9065.1] (SZ 2014). - A faj nyugat-dunántúli előfordulási adatait KIRÁLY et al. (2007) ismertetik. A nyugati határszéli területeken (Kőszegi-hegység, Őrség, Soproni-hegység) kívüli alacsonyabban fekvő dombvidéken és a Rába-völgyben a faj igen szórványos, kis példányszámú állományokkal van jelen. Ezeket egészítik ki a Bejcgyertyános és Sárvár határában fellelt állományok. A Farkas-erdő telepített duglászfenyő állomány tűlevél avarján több (20-25 tő) fiatal illetve idősebb, nagyméretű példány láthatóan szaporodóképes populációt alkot.

54. Dryopteris affinis (Lowe) Fraser-Jenk - AKH: Csehimindszent, Farkas-erdőben ritka [8867.4] (KG-MA 2011). - A Kőszegi-hegység, a Soproni-hegység, az Őrség és a Vendvidék területén szórványosan megjelenő páfrány (KIRÁLY 1996, BoDONCZI 1999, KIRÁLY 2004, KIRÁLY et al. 2002). BodonCZI (2002) a Vasi-Hegyhát területén is megtalálta. KIRÁlY et al. (2007) többek között a Sopron-Vasi síkról (Sopronhorpács, Iván) is közöl előfordulási adatokat. Az Alsó-Kemeneshát területéről korábban nem volt ismert az előfordulása.

59. Blechnum spicant (L.) Roth. - AKH: Bejcgyertyános határában a Farkas-erdő telepített selyemfenyő állományában 2 tő [8867.4] (KL 2013). - Hazánkban csak a nyugati határszélen az Őrség és a Vendvidék területén ismertek stabil kis egyedszámú populációi (BODONCZI 1999, KIRÁLY et al. 2002). Időnként feltűnnek egyéb alkalmi megtelepedései például Csepreg mellett (PAPP 1954) - de ezek a legtöbb esetben nem bizonyulnak hosszútávon életképesnek. A faj ökológiai tűrőképességének határán hazánkban a bejcgyertyánosi az eddig ismert legkeletibb előfordulás.

152. Thesium dollineri Murb. subsp. dollineri - AKH: Sitke, Hercseg-hegy felhagyott gyümölcsös gyepjében néhány tő [8768.3] (KL 2011). - Országosan is ritka, veszélyeztetett gyomnövény. A Nyugat-Dunántúlon korábban csak 1876-ban a Zala megyei Nagykapornak mellett gyüjtötte Wiesbaur J. B. (BP-418152). 
174. Fallopia sachalinensis (F. Schmidt) Ronse Decr. - FKH: Felsőszölnök, János-hegy út menti törmelék lerakóhelyen egy nagyobb folt [9163.1] (MA 2010). - Téves szombathelyi adata Priszter Szaniszlótól (Soó 1985) még a hibridfaj itthoni ismerete előtti időből származik. Legközelebb az ausztriai Güssing várhegyén él (BALOGH ex verb.), mely a felsőszölnöki előfordulástól légvonalban $25 \mathrm{~km}$-re található. A Vendvidékre valószínűleg Ausztriából származó törmelékkel együtt hurcolták be, mivel a megtalálás helyével szomszédos ház osztrák tulajdonban van. A Nyugat-Dunántúlon a most közölt felsőszölnöki a faj első hiteles adata.

194. Rumex pulcher L. - NYBS: Zalakomár, bivalyrezervátum területén legelt gyepekben tömeges [9469.1] (MA 2013). - Hazánkban ritka faj, leginkább az ország déli részén található meg (KIRÁLY 2009). Zalakomár mellett hasonló, intenzíven legelt száraz gyepekben él, mint a Dél-Dunántúlon. A környéken más legelőn nem került elő, ezért feltételezhető, hogy az itteni állomány behurcolás eredménye. A Nyugat-Dunántúlról korábban nem jelezték.

205. Polycnemum heuffelii Láng - NYBS: Miháld, erdei út szegélyében bolygatott felszínen néhány tő [9568.2] (FS 2009). - Egész elterjedési területén ritka faj. Hazánkban csak néhány aktuális adata ismert (MESTERHÁzy 2007, KovÁcs 2014). Korábban a változattól a faji szintig több taxonómiai rangon is tárgyalt taxon feltételezhetően csak a $P$. arvense árnyékban növő alakja. A hazai gyüjteményekben lévő herbáriumi példányok jelentős része erdőkből vagy legalábbis árnyékos termőhelyekről származik. A faj aktuális adatai is sűrű növényállományokból (gyomos búzatarló) vagy erdőkből származnak. A korábban közölt kemenesháti élőhelyen ráadásul az állományban találhatók a $P$. arvense bélyegeit mutató egyedek is (MESTERHÁZY 2007). A P. heuffelii gyenge taxonómiai státuszát erősíti a nemzetségen a közelmúltban elvégzett molekuláris genetikai vizsgálat is (MASSON \& KADEREIT 2013). A miháldi lelőhely már nem kifejezetten a Nyugat-Dunántúlhoz köthető, de mivel országosan is ritka taxonról van szó és az előfordulás közvetlen a régió határterületéről származik, ezért célszerűnek tartottuk jelen munkában való közlését.

206. Polycnemum majus A. Braun. - AKH: Vásárosmiske, Nemes-hegy bazalt kőfejtőjében [8768.3] (MA 2010). - MESTERHÁZY et al. (2003) korábban P. arvense-ként közölték a jelzett helyről, de a későbbi herbáriumi revízió és a populáció ismételt vizsgálata alapján nyilvánvalóvá vált, hogy a területen a $P$. majus él. A Nyugat-magyarországi-peremvidéken korábban nem volt ismert a faj előfordulása.

207. Polycnemum arvense L. - AKH: Kenyeri, reptér parlagjain szórványosan [8668.2] (MA 2007); Nagysimonyi, a településtől északra szántószegélyben néhány egyed [8768.1] (MA 2010); Ostffyasszonyfa, Pannonia-ring kavicsos, bolygatott felszínén néhány tő [8668.3] (MA 2007); Vönöck, a településtől északra szántószegélyben szórványosan [8668.4] (MA 2008). RTS: Sárvár, belterület [8767.2] (KL 2013). - A torzonok közül NyugatMagyarországon a leggyakoribb faj, ennek ellenére viszonylag kevés aktuális adata ismert. Pionír növény, mely elsősorban sovány talajú szántók tarlóaszpektusában, vaddisznótúrásokban és más bolygatott felszíneken jelenik meg, néha urbánus környezetben. A tápanyagban gazdag termőhelyekről hiányzik.

208. Polycnemum verrucosum Láng - AKH: Kenyeri, reptér taposott felszínein kevés egyed [8668.2] (MA 2010); Csönge, a településtől délre akácültetvény gyomirtózott sorközeiben számos egyed [8668.4] (MA 2008). ELD: Nagykanizsa-Sormás, volt katonai gyakorlótér homokbuckáinak bolygatott felszínén szórványosan [9567.2] (MA 2010). - A Polycnemum heuffelii-hez hasonlóan szintén kétes taxon. A populációkat több éven keresztül vizsgálva megállapítható, hogy azokban változnak a $P$. arvense és a $P$. verrucosum habitusú egyedek, sőt a legtöbb populációban általában mindkét faj egyedei is fellelhetók. A $P$. verrucosum típusú egyedek általában a nagyon sovány vagy taposott termőhelyen nőnek, míg a $P$. arvense típusúak inkább a növényzettel jobban benőtt, jobb vízháztartású részeken. A $P$. verrucosum 
és a $P$. heuffelii taxonómiai helyzetének tisztázásához leginkább azok azonos termőhelyen való nevelésével végzett kísérletek vezethetnek eredményre.

213. Chenopodium botrys L. - AKH: Sárvár-Hegyközség, belterületi út padkáján [8767.4] (KL 2012). RTS: Ikervár, szélturbinák szervizútján [8767.3] (KL 2012); Sárvár belterület, bazaltzúzalékos parkolóban [8767.2] (KL 2013); Ölbö-Alsószeleste vasútállomás rakodóján 1 tő [8767.1] (SD 2015). FKH: Ôriszentpéter, Őri-ÉK-1 kutatófúrás bazalttal felszórt alapján gyakori [9164.4] (MA 2011). - Elsősorban bolygatott élőhelyeken megjelenő növény. A Nyugat-Dunátúlon kifejezetten ritka. A cáki kőfejtőből és a Kőszegről származó adatai több mint száz évesek (FrEH 1883, WAISBECKER 1908). Ugyancsak az 1800-as évek végén az AlsóKemenesháton található Csönge településen is gyưjtötték (Piers V. 1889, SAMU). A Rábától délre korábban csak Pusztaszentlászló és Murakeresztúr községekből került elő a múlt század közepén (Károlyi Á. 1957, BP-398895, illetve Boros Á. 1922, BP-421385). Az ikervári, őriszentpéteri és sárvári előfordulások nagy valószínűséggel behurcolás eredményei, melynek forrása a Keszthelyi-hegység lábánál fekvő Bazsi település melletti bányából származó bazaltzúzalék.

220. Chenopodium vulvaria L. - GYS: Sorokpolány belterületén házfal tövében néhány egyed [8866.3] (MA 2006). RTS: Sárvár, a Várpark gyalogösvényén [8767.2] (KL 2012). RS: Völcsej, a katolikus templom környékén, házfalak tövében [8566.2] (KG 2006). - A NyugatDunántúlról csak kevés és régi előfordulási adattal rendelkező faj (BORBÁs 1887). Gyüjtései ismertek Sorkikápolna (Márton J. 1890, BP-46131), Nagykanizsa (Károlyi Á. 1950, BP292910), Sormás (Károlyi Á. 1964, BP-403596), Gősfa (Károlyi Á. 1952, BP-292909) településekről. Újabban JEANPLONG (1999) közölte Vasvárról. A most fellelt állományai jellemzően települések belterületéhez köthetők. Leginkább a régi házak falainak tövében, lehulló és porladó vakolat között jelenik meg. KIRÁLY (2004) Sopronban szintén hasonló termőhelyen találta.

316. Sagina apetala Ard. subsp. erecta (Hornem.) F. Herm. (Syn: Sagina micropetala Rauschert) - KV: Lendvadedes, a víztározó melletti parkoló nyílt felszínein [9465.1] (MA 2008). - A tőalak a településeken gyakori fajnak számít, ezzel szemben az alfaj a térségben igen ritka. A Kőszegi-hegységből csak az osztrák oldalon volt korábbi adata (TRAXLER 1984). Újabban PinKE et al. (2003) találták néhány extenzív szántón Katafa és Sopron térségében. Két korábbi gyűjtése Szőcéről (Boros Á. 1954, BP-424733) és Nagykanizsa környékéről (Károlyi Á. 1962, BP-295044) származik.

318. Sagina subulata (Sw.) C. Presl. - AKH: Sitke, Sitkei-erdő, erdei úton [8768.1] (KL 2011). - A Nyugat-Dunántúlon szórványosan megjelenő faj, amelynek aktuális adatait KIRÁLY et al. (2007) közlik. A Savaria Múzeumban találhatók Jeanplong József Ivánból származó herbáriumi lapja (BALOGH \& KULCSÁR 2013).

326. Herniaria hirsuta L. - AKH: Sótony, gabonavetésben [8867.2] (KL 2011). - Jellemzően pionír talajfelszíneken vetésekben, egyéves parlagon, útszéleken megjelenő apró termetű, heverő szárú nem éppen feltűnő megjelenésű növény. Talán ez is hozzájárul ahhoz, hogy viszonylag kevés lelőhellyel dokumentált faj a Nyugat-Dunántúlon. Korábban Jeanplong József 1951-ben gyüjtötte Szombathelyen (BALOGH \& KULCSÁr 2013). Aktuális adatait a Soproni hegységből KIRÁLY (2004), a Kemeneshát több pontjáról - Alsóújlak, Vasvár, Egervölgy, Szemenye, Káld - PINKE et al. (2003) közlik.

330. Spergula pentandra L. - ZH: Belezna, vasútállomás környékén, parlagon [9667.3] (MA 2008). - Zala megye déli részének homokos területein Zalaszentjakab (1953, BP-295506), Hosszúvölgy (1956, BP-295508) és Homokkomárom (1953, BP-248538) mellett gyüjtötte Károlyi Árpád. Ezek az előfordulások a belső-somogyi állományok északi határát rajzolják ki. A régi zalai adatokat az intenzív kutatás ellenére sem sikerült megerősíteni, csak egy Belezna környéki homokos parlagról került elő alacsony egyedszámban. Megtalálását nehezíti, hogy gyakran a hozzá hasonló Spergula arvensis állományában szálanként jelenik meg. 
416. Pulsatilla nigricans Störck. - AKH: Nagysimonyi, szőlőhegyen, szőlők közötti gyepben, százas egyedszámban [8768.1] (MA-KL 2012); Kemenesmihályfa, a településtől északnyugatra lévő cserjésedő legelőn néhány tő [8768.2] (MA 2007). - A térségünkben soha nem volt gyakori faj, de az utóbbi évtizedekben még inkább visszaszorulóban van. Élőhelyeit leginkább a művelés (legeltetés, kaszálás) felhagyása miatt bekövetkező cserjésedés veszélyezteti (például a Kissomlyón található állomány). Igen érdekes a Nagysimonyi szőlőhegyen előkerült populáció, amely egy hétvégi telek fúnyíróval nyírt gyepjében található. Az állomány szemmel láthatóan jól érzi magát, és az alacsonyra nyírt gyepben terjed, mivel az első fünyírás idejére termései rendszerint már beérnek.

496. Sisymbrium strictissimum L. - RS: Répceszentgyörgy, a Répce-folyó menti facsoportok üde szegélyében [8667.1] (MA 2006); Gyalóka, Zsira, Répcevis, az államhatártól a településig a Répce mentén több helyen [8565.2, 8566.1, 8566.3] (KG 2003). PS: Felsőcsatár, a falutól délre, a Pinka-patak jobb partján magaskórós növényzetben [8764.4] (SZ 2005). - Aktuális előfordulásait a Soproni-hegységből KIRÁLY (2004) ismerteti. Ezen kívül csak BoRBÁs (1887) szombathelyi és WAISBECKER (1895) kőszegdoroszlói adata említhető. Feltételezhetően a területünkre az Alpok előteréből jutott le a Pinka- és a Répcefolyó közvetítésével. A régióhoz legközelebb a Somlón lévő üde erdőkben fordul elő (MESTERHÁZY et al. 2003).

498. Sisymbrium orientale L. - RTS: Sárvár, belterület [8767.4] (KL 2014). - A faj a NyugatDunántúlon elsősorban a Fertőmelléki-dombsorról a Laitaicum flórajárás területéről ismert (KIRÁLY 2001, PINKE et al. 2003). TRAXLER (1984) a szomszédos Burgenland területéről is közli. Sárváron egy közút melletti zöldterületből került elő néhány töve. Valószínúleg a növény magja egy gépjárművel kerülhetett oda. A növényt 2015-ben a város más pontján is megtaláltuk.

516. Hesperis tristis L. - AKH: Kenyeri, reptér, cserjésedő száraz gyepben [8668.2] (SD 2013). - Nyugat-Magyarországról csak régi Soproni-hegységből származó adatát (GoMBOcz 1906) és a Fertőmelléki-dombsoron lévő aktuális előfordulását (KIRÁLY 2001) ismerjük, azonban a szomszédos Kisalföld számos pontján megtalálható (PoLGÁR 1941). A Kemenesháthoz legközelebb Pápa környékén vannak aktuális adatai (MESTERHÁzY ined.). Kenyeri környékén az Alsó-Kemeneshát („Cser”) fennsíkján lévő löszös foltokon számos Kisalföldön előforduló faj megtalálható (Chrysopogon gryllus, Adonis vernalis, Allium sphaerocephalon), melyekkel analóg a Hesperis tristis előkerülése.

518. Hesperis sylvestris Crantz - ZH: Nagykanizsa-Sormás, üde, cserjésedő magaskórósban [9567.2] (MA 2005). - Magyarországon ritka, hiányosan ismert faj. Ritkasága kifejezett Nyugat-Magyarországon, ahol korábban csak KÁRoLYI et al. (1972) közli Zákány mellől, illetve JEANPLONG (1983) Szombathely és Torony környékéról. Újabban KIRÁLY et al. (2007) ismertette egyetlen adatát Petőhenyéről. Valószínúleg nem kötődik kifejezetten erdőkhöz, hanem inkább üde szegélyek, cserjések, magaskórósok növénye.

538. Cardamine parviflora L. - GYS: Vát, Váti erdő, Kőris-patak melletti égeresben [8766.2] (KL 2013). RTS: Sárvár, belterületi virágágyásban [8767.2] (KL 2014). - A faj aktuális Nyugat-Dunántúli előfordulási adatait KIRÁLY et al. (2007) ismertetik. Ebből is kitűnik, hogy a faj a térségben meglehetősen ritka. Elsősorban a Kisalfölddel határos területeken jelenik meg kis egyedszámban. A Váti-erdőben jó vízellátású égeres aljnövényzetében találtuk. A sárvárihoz hasonló virágfölddel történő behurcolásból származó adventív megjelenéséről már KIRÁLY (2004) is beszámolt.

570. Draba muralis L. - KZD (G): Pördefölde, erdei kisvasút bazaltkövein [9466.1] (MA 2006). ELD: Csapi, szőlőhegy bolygatott felszíneken [9468.4] (MA 2007). SM: Sopron, Ikvamenti réten [8265.3] (KL 2014). - A faj elterjedése a térségben túlnyomórészt a DélnyugatDunántúlra koncentrálódik. A korábbi irodalmi adatai is ebből a térségből származnak (KÁROLYI \& Pócs 1957). A Nyugat-Dunántúl más részein szinte ismeretlen. Újonnan fellelt 
állományai közül kitűnik a Sopron melletti, mely az elterjedési területének súlypontjától jóval távolabbra esik.

582. Teesdalia nudicaulis (L.) R. Br. - ZH: Belezna, szántóföld szegélyében tömeges [9667.4] (MA 2008); ZH: Ốrtilos, Őrtilosi-erdő útszegélyeiben, tűzpásztáin szórványos [9667.4] (MA 2008). - Hazánkban először az Őrtilosi-erdőből került elő a faj (KÁROLYI \& Pócs 1957), majd hosszú ideig itt nem találták meg. FARKAS (1999) aktuális őrtilosi előfordulását már nem is említi. Jelen adatok azonban megerősítik, hogy a faj még napjainkban is él a területen. A szomszédos Belső-Somogyban még több helyen megtalálható, jellegzetes élőhelyei a bolygatott ezüstperjés gyepek és a savanyú homokon lévő tűzpászták (LÁJER 2005). Szántókról korábban nem jelezték.

603. Coronopus squamatus (Forssk.) Asch. - RS: Tormásliget, földút szegélyében néhány egyed [8566.4] (MA 2005). - Az egész Dunántúlon rendkívül ritka fajnak csak Szombathelyről volt korábbi adata (GÁYER 1913). Újabban PINKE et al. (2003) közlik völcseji előfordulását. Feltehetőleg a térség északi, Kisalfölddel érintkező mezőgazdasági területein elterjedtebb lehet, csak élőhelyein jár kevés botanikus.

622. Calepina irregularis Adans. - RS: Csapod, telepített akácosban tömeges [8467.4] (MA 2007). AKH: Sitke, „Kocsok” száraz gyepben tömeges [8768.3] (MA 2013). - A NyugatDunántúlról korábban KÁROLYI \& PóCS (1964) jelzi Zalaapáti környékérôl. Az általunk megtalált állományok valószínűleg adventív megtelepedések. A régióhoz legközelebb a Balaton északnyugati régiójában fordul elő, ahol útszéleken, mezsgyéken néhol tömeges (MESTERHÁZY ined.).

719. Potentilla rupestris L. - AKH: Sitke, Sitkei-erdő, erdészeti út padkáján [8768.1] (KL 2011); Bejcgyertyános, Farkas-erdő, bükkös szegélyében [8867.2] (MA 2012). Fő: Rönök, Alsórönöktől északra az egykori nyomsávi út szegélyében néhány tő [9064.1] (SZ 2006). A faj nyugat-dunántúli aktuális előfordulási adatait KIRÁLY et al. (2007) ismertetik. Ezeket egészítik ki az Alsó-Kemenesháton újonnan előkerült állományok. A Sitkei-erdőben a fajt Filarszky már 1909-ben gyüjtötte (KIRÁLY et al 2007). Jeanplong József 1989-es Ostffyasszonyfa melletti tölgyesből származó gyűjtése vélhetően szintén a Sitkei-erdőből származik (BALOGH \& KULCSÁR 2013). A Felső-Őrségből korábban nem közölték.

822. Cerasus vulgaris Mill. subsp. acida (Dumort.) Dostál - FKH: Szốce, a település környékén lévő erdőkben, faültetvényekben több helyen kivadulva [9165.1, 9065.3, 9065.4] (MA 2010). - BALOGH et al. (2004) szerint meghonosodott neofiton, melynek hazai inváziós megjelenéséről nem találtunk adatot. A Nádasdi-fennsík déli részén lévő változó vízhatású területeken lévő erdei fenyő ültetvényekben, degradált fenyőelegyestölgyesekben terjedőben van, de jelentősebb inváziója egyelőre csak Szőce környékén figyelhető meg. A Nyugat-Dunántúl flórájára új taxon.

911. Lathyrus nissolia L. - Fô: Nemesmedves, Nemesmedves és Vasszentmihály közötti közút közelében földút cserjésedő szegélyében néhány egyed [9064.1] (SZ 2014). - A Nyugat-Dunántúlon ritka faj (Soó 1966). Aktuális előfordulásai a Göcsejből (PINKE et al. 2005) és a Répce-síkról (KIRÁLY et al. 2007) ismertek, ahol mindenütt csak kevés példányszámban található meg. A faj leginkább a kötött, agyagos talajokon lévő parlagokon, mezsgyéken, száraz gyepekben jelenik meg.

1047. Euphorbia villosa Waldst. et Kit. - FKH: Szalafö, erdei utak kékperjés szegélyében [9163.2] (MA 2007). - A faj északnyugat-dunántúli aktuális adatait KIRÁLY et al. (2007) foglalja össze. Az Őrségből csak régi előfordulásai ismertek (GÁYER 1925, KÁROLYI \& Pócs 1969). Bár KÁROLYI \& PóCS (1969) a faj élőhelyéül ligeterdőket, magassásosokat, lápréteket nevez meg, azonban az Őrségben szinte mindig kékperjés erdőszegélyben vagy útrézsűben él. Hasonló élőhelyről korábban JEANPLONG (1983) is közölt adatot Nárai mellől.

1048. Euphorbia seguieriana Neck. - AKH: Borgáta, a 84-es út rézsújében [8868.1] (KL 2012). - A Nyugat-Dunántúlon ritka faj. Egyedül a Fertőmelléki-dombsor vegetációjában 
(Laitaicum) elterjedt (KIRÁLY 2001). Ezeken kívül a térségből két irodalmi adatát ismerjük BORBÁs (1887) a Ság-hegyről, KESZEI (2000b) a Kenyeri reptér száraz gyepjéből jelezte. A faj a Ság-hegyrôl újabban nem került elő (MESTERHÁZY et al. 2003).

1078. Polygala amarella Crantz - AKH: Vashosszúfalu, Ódorfai téglagyár melletti fiatal tölgytelepítésben [8868.3] (MA 2013). - Térségünkben ritka faj, aktuális adata csak a Kőszegi-hegységből (KIRÁLY 1996) és a Sopronkőhidai-medencéből (KIRÁLY G. ex verb.) ismert. Korábban Zala megye néhány pontjáról (Nagykanizsa környéke, Károlyi Á. 1942, BP-480161; Batyk, Nagy É. 1954, BP-238216; Muraszemenye, Károlyi Á. 1948, BP-480462) és Sopron környékéről (Ágfalva, Kárpáti Z. 1944, BP-198385; Tómalom, Kárpáti Z. 1932, BP-390686) gyűjtötték. Jó víztartóképességű agyagos talajokat, szivárgóvizes vagy a talajvíz által befolyásolt termőhelyeket kedveli. A termőhelyek kiszáradása miatt számos korábbi élőhelyéről eltűnt.

1163. Viola elatior L. - SM: Sopron, Ikva-menti réten [8265.3] (KL 2011). - A térségből nagyon kevés adata ismert. WALLNER (1903) és GOMBOCZ (1906) a Soproni-hegységből, GÁYER (1927) Rum határából, míg KÁROLYI et al. (1971) Gősfa mellől jelezték a növény előfordulását. Jeanplong Józsefnek az iváni Alsóerdőből származó herbáriumi lapja (1951) a Savaria Múzeumban található (BALOGH \& KULCSÁr 2013). Újabban a Répce-sík és a Fertőmelléki-dombság néhány pontjáról is előkerült (KESZEI 1997, KIRÁLY et al. 2007).

1224. Epilobium palustre L. - VHH: Kétvölgy, Grajka-patak völgyének szivárgóvizes magassásosaiban [9163.1] (MA 2007); Orfalu, Hársas-patak völgyének legfelső szakaszán lápréten [9163.1] (KG 2009); Farkasfa, focipálya mellett zsombéksásos lápban [9163.2] (KG 2010). FKH: Kondorfa, a településtől nyugatra vágásterület nedves helyein [9164.1] (KG 2010). - Korábban a Délnyugat-Dunántúl több pontjáról is jelezték (BORBÁs 1887, PócS et al. 1958, KÁROLYI \& Pócs 1964, 1968) napjainkban azonban csak a Vendvidékről került elő. A Kőszegi-hegységből (WAISBECKER 1891) és a Soproni-hegységből (KÁRPÁTI 1949) csak régi adatai vannak. Jó vízellátottságú zsombéksásosok, úszólápok, szivárgóvizes lápok növénye. Termőhelyének vízviszonyaira rendkívül érzékeny, igényli, hogy annak talaja egész évben nedves legyen. Megfogyatkozása az élőhelyek kiszáradásával és szukcessziójával magyarázható.

1227. Epilobium obscurum Schreb. - FKH: Szôce, láprétet tápláló forrás szivárgóvizes helyein [9165.1] (MA 2006). - Pócs et al. (1958) korábbi adatának megerősítése. A Délnyugat-Dunántúlon korábban csak Lispeszentadorjánból jelezték (KÁROLYI \& Pócs 1957). Előfordulási adatainak csekély száma egyrészt nehéz felismerhetőségén is alapszik, másrészt a források vízhozamának csökkenésével élőhelyei is visszaszorulóban vannak.

1237. Hippuris vulgaris L. - ZH: Garabonc, a település déli végében út menti árokban kis állomány [9468.2] (MA 2006). - Nyugat-Magyarországon rendkívül ritka faj, melynek mindössze két korábbi irodalmi említése ismert. A vas megyei Petőmihályfa mellől GÁYER (1932) jelezte. Ezt az adatot azonban később nem sikerült megerősíteni. A település környékén lévő lápréteket a múlt század közepén lecsapolták, így a faj eltúnése valószínűsíthető. KÁROLYI \& Pócs (1964) a régióval szomszédos Dráva-síkon Őrtilosból közölték, pontos helymegjelölés nélkül. Ugyanitt a település kavicsbányájában a fajnak ma is erős populációja él (KIRÁLY G. ex verb.). Az újonnan megtalált állomány a nagy forgalmú út és a település közelsége miatt erősen veszélyeztetett. A közelből aktuálisan csak a KisBalaton néhány csatornájából ismert a faj előfordulása (VIDÉKI R. ex verb.). Említésre érdemes, hogy a fajt az akvaristák is használják, és néha természetes vizekbe is kihelyezik. Ilyen jellegü adventív megjelenés ismert a Soproni-hegységben (SCHMIDT D. ex verb.).

1266. Libanotis pyrenaica (L.) Bourg. - AKH: Vásárosmiske, Púpos-hegy lejtősztyepjében [8768.3] (KL 2005). - Száraz tölgyesek, sztyeprétek faja, amely a Nyugat-Dunántúlon meglehetősen ritkának számít. A szomszédos kisalföldi területeken főleg útmezsgyéken él (SCHMIDT D. ex verb.). A Soproni-hegységből csak száz éves adatai ismertek (GomBocz 1906). 
JEANPLONG (1972) a sitkei Hercseg-hegyről, KovÁCS (1996) a Kissomlyóról, KIRÁLY (1996) a Kőszegi-hegységből közölte előfordulását.

1276. Oenanthe banatica Heuff. - MBS: Letenye, Mura menti füzligetben [9566.3] (MA 2008) (ugyanitt ugyanebben az évben a fajt Kevey Balázs is megtalálta lásd (KEvEY 2015). A Nyugat-magyarországi peremvidéken korábban teljesen ismeretlen fajt, a közelmúltban az osztrák-magyar határtól nem messze, a Strém-patak egyik égerligetében - Ausztriára újként - is megtalálták (FISCHER \& NIKLFELD 2008). Horvátországból ismert ugyan, de állományai a Murától csak jóval délebbre fordulnak elő. Azon „illír-dácikus harapófogó” fajaink egyike, melyek a Kárpát-medencébe két migrációs útvonalon az Alpok és a Kárpátok előterében jutott fel.

1311. Peucedanum officinale L. - AKH: Kemenessömjén, változó vízhatású cseres-tölgyes szegélyében erős állomány [8668.4, 8768.2] (MA 2013). - A térségben csak Vitnyéd mellől (CSAPODY 1953) volt régi hiteles adata. Később a cséri szikeseken is előkerült (KESZEI 2000a), majd újabban az Alsó-Kemenesháton Egyházaskesző mellől KIRÁLY et al. (2007) említik. Az újonnan megtalált állomány az egyházaskeszőihez hasonló kiligetesedő cserestölgyesben található, melyek korábban legelőerdők voltak. Napjainkban az akác ültetése, valamint spontán terjedése miatt a cseres-tölgyesek és azok szegélyvegetációja nagymértékben veszélyeztetetté vált. A folyamat a $P$. officinale új termőhelyét is érinti. A most felfedezett élőhely néhány száz méteres sugarában található sűrű cserjésekben még napjainkban is található a faj néhány túlélő egyede, ami valószínűsíti, hogy az AlsóKemeneshát változó-vízhatású legelőerdeiben korábban jóval elterjedtebb lehetett.

1385. Gentiana pneumonanthe L. - RV: Ikervár és Sótony között a Herpenyő-patak melletti réten százas egyedszámú állomány. [8767.4] (KL 2012). - Az Őrség kékperjés láprétjeinek szórványos faja, melynek a Rába-völgyéből már csak kevés előfordulása ismert. Korábban JEANPLONG (1972) közli a szarvaskendi Rába ártérről, valamint KovÁCS \& TAKÁCS (1998) az alsószölnöki láprétekről. Újabban Bejcgyertyános határában a Herpenyő-menti mocsárréten (KULCSÁR \& MESTERHÁZY 2008) és a Hollósi-erdőtől keletre lévő mocsárréten (Kovács et al. 2000) is előkerült. MEsTERHÁZy (2013) a Hollósi-erdő kékperjés tisztásán találta. A térségünkben még a Répce-menti réteken élnek erős populációi (KESZEI 1997).

1425. Pulmonaria angustifolia L. - AKH: Sitke, szőlőhegyen szálkaperjés gyepben erős állomány [8768.1] (MA 2013). - Országszerte visszaszorulóban lévő, a térségben nagyon kevés adattal rendelkező faj (KIRÁLY et al. 2007). Az Alsó-Kemeneshátról korábban HORVÁTH (1978) jelezte Ostffyasszonyfa környékéről, de ezt az adatot később nem sikerült megerősíteni. Leginkább felhagyott szőlők vagy legelőerdők szálkaperjés, regenerálódó gyepjeiben él. Az élőhely cserjésedésével kiszorul, így viszonylag rövid ideig tartó szukcessziós stádiumban érzi jól magát.

1457. Omphalodes scorpioides (Haenke) Schrank - AKH: Sárvár, Saroltamajor mellett a Kemeneshát letörésén található gyertyános-tölgyes erdő szivárgó vizes élőhelyen [8767.2] (MA-KL 2012). RV: Bejcgyertyános, Herpenyő-patakot kísérő ligetekben [8867.3] (KL 2012). RTS: Sárvár, Csónakázó-tó melletti parkerdőben [8767.4] (KL 2013). - A faj aktuális nyugat-dunántúli előfordulási adatait KIRÁLY et al. (2007) ismertetik. A Rába-menti lelőhelyeit MESTERHÁZy (2013) foglalja össze. Az újonnan fellelt állományok tovább pontosítják a faj nyugat-dunántúli elterjedésére vonatkozó ismereteinket.

1490. Galeopsis ladanum L. - AKH: Sitke, genyőtés-tölgyes bolygatott szegélyében elszórtan [8768.1] (MA 2013). - WAISBECKER (1891) a Kőszegi-hegység egyes szántóin gyakorinak jelzi, Zalából KÁRolYI et al. (1971) még a múlt század közepéből is számos adatot közöl. Napjainkra az extenzív művelésű, sovány talajú szántók megfogyatkozásával a faj erőteljesen visszaszorult. Legutóbb Zala megye két pontjáról jelezte PINKE et al. (2005). A sitkei állomány ezektől az adatoktól eltérően nem szántón, hanem zavart mészkerülő 
cseres-tölgyes tisztásán került elő. A sitkeihez hasonló élőhelyen történő előfordulások az Északi-középhegységbőll is ismertek (CsIKY 2004).

1542. Lycopus exaltatus L. - GYS: Ölbő, „Pap-tó” gyepjében [8767.1] (KL 2011). RS: Csér, téglagyári tavak [8567.4] (KG 2009). - A térségben ritka faj. Csak régi - több mint száz éves - irodalmi adatait ismerjük a Kőszegi-hegységből (WAISBECKER 1882, FrEH 1883) és Sopron mellól (Goмвосz 1906). A L. europaeus-szal ellentétben nem kötődik kifejezetten a vizes élőhelyekhez, hanem mezofil erdőszegélyekben vagy magaskórósodó gyepekben is előfordul.

1560. Salvia austriaca Jacq. - ELD: Pusztaszentlászló, temető mellett száraz gyepben néhány tő. [9367.3] (MA 2007). - A Nyugat-Dunántúlról korábban nem volt ismert. Legközelebb Csurgó helymegjelöléssel említi HÉJJAS \& BoRHIDI (1960), valamint a Kőszegihegység osztrák oldaláról van egy régi adata (BORBÁs 1887). Bár a jelen munkában közölt pusztaszentlászlói adat egy jó természetességű mezofil gyepből származik, az alacsony példányszámú állomány és az élőhely melletti jelentős gépkocsiforgalom ténye felveti a behurcolás lehetőségét. Az adventív megtelepedés gyanúját erősíti az is, hogy a környező hasonló adottságú gyepekben nem találtuk meg a fajt.

1623. Digitalis lanata Ehrh. - MBS: Muraszemenye, a településtől délre lévő kavicsbánya degradált felszínén nagy egyedszámban, közvetlenül a Mura mellett [9565.2] (LA 2009). A faj hazai őshonossága kérdéses (vö. KEVEY \& PoZSONYI 2003), mivel régóta gyógynövényként termesztik és számos esetben kivadulva jelenik meg a természetes areáján kívül. Bár a hazai állományok zöme sziklagyepekben, pusztafüves lejtőkön és löszgyepekben él, a növény számos esetben jelenik meg bolygatott vagy másodlagos élőhelyeken. Mivel a Mura menti előfordulás közelében nem ismert termesztése, magja valószínűleg a folyó közvetítésével vagy a bányában dolgozó munkagépekkel kerülhetett a területre. A Mura mente szlovén területén nem ismert (vö. BAKAN 2006). A NyugatDunántúl flórájára új faj.

1625. Pseudolysimachion longifolium (L.) Opiz. - AKH: Sótony és Bejcgyertyános közötti közút melletti árokban [8867.2] (KL 2012). - A Nyugat-Dunántúlon üde mocsárréteken még nem számít ritkaságnak, az Alsó-Kemenesháton azonban a faj számára kedvező élőhely hiányában igen ritka. A most fellelt állománya sem természetes élőhelyhez köthető, mivel a közút melletti vízelvezető árokból került elő.

1646. Veronica dillenii Crantz. - VH: Felső́csatár, Vas-hegy nyílt sziklagyepében alacsony egyedszámban [8764.4] (MA 2006). - KÁROLYI \& Pócs (1964) Lenti és Őrtilos környékérôl jelzi. Utóbbi helyen az Ốrtilosi-erdőben még napjainkban is megtalálható (MESTERHÁzY ined.). A közelmúltban a Harkai kúpon (KIRÁLY et al. 2005) került elő, ahol élőhelye a jelen munkában közölt felsőcsatárihoz hasonló, mivel a faj mindkét helyen nyílt szilikátsziklagyepben él. A Vas-hegyen lévő sziklagyepeket a Felsőcsatár mellett létesült kőfejtő és a talkumbánya gyakorlatilag teljesen tönkretette. Napjainkra mindössze egyetlen jó állapotú sziklakibúvás maradt fenn, ahol a Veronica dillennii állománya is megtalálható.

1662. Melampyrum barbatum Waldst. et Kit. - AKH: Borgáta mellett a 84-es út rézsűjében [8868.1] (KL 2012). ELD: Kisbucsa, a településtől délre lévő kis domb homokbányájának szegélyében [9167.4] (MA 2015). VH: Felső́csatár, a településtől északra, az országút rézsújében [8764.4] (SZ 2014). - A Nyugat-Dunántúlon a faj aktuális előfordulásait a Fertőmelléki dombsorról (KIRÁLY 2001) és a Soproni-hegységből (KIRÁLY 2004) ismerjük. Korábban a Délnyugat-Dunántúl számos pontról közölték löszös szántók szegélyéből (KÁROLYI et al. 1971). A Savaria Múzeumban Jeanplong József régi herbáriumi lapjai találhatók, aki a fajt Cák (1938) és Iván (1951) határában gyűjtötte (BALOGH \& KULCSÁR 2013).

1693. Orobanche pancicii Beck. - ELD: Szemenyecsörnye, Aligvár, domb lábánál lévő degradált, kiritkuló gyertyános-tölgyesben Knautia drymeia foltokban számos egyed 
[9565.2] (MA-LA 2009). - Aktuális adatai a Kőszegi-hegységből és Nagykanizsa környékéről (Szepetnek) ismertek, de korábban az Egerszeg-Letenyei-dombság déli részének néhány pontjáról (Obornak, Bázakerettye, Homokkomárom) is gyüjtötték (KIRÁLY et al. 2005). Az aligvári lelőhely a faj harmadik aktuális hazai adata.

1777. Valerianella dentata (L.) Pollich. - GYS: Csényei Tilos-erdő, földút szegélyében [8767.3] (KL 2014). - A térségben szórványosan megjelenő faj. JEANPLoNG (1999) Nárai mellett szántóföldön találta. PINKE et al. (2003) Katafa, Fertőrákos és Harka településekről jelzik az előfordulását. Jeanplong József korábban Szombathely, Gór és Lukácsháza határából is gyújtötte (BALOGH \& KULCSÁR 2013).

1785. Dipsacus pilosus L. - ZH: Orosztony, a településtől délre, patakmenti égeresben [9368.3] (MA 2005). RS: Mesterháza, Laskod-erdő, Répce mentén gyomos, áréri magaskórósban [8667.1] (MA 2008). - Délnyugat-Dunántúlról viszonylag sok adatát ismerjük (BORBÁs 1887, KÁROLYI \& PóCS 1969), de napjainkban itt sem tekinthető gyakori fajnak. A régió északi részén csak kevés lelőhelye van, ezek is nagyrészt a közelmúltból származnak (KIRÁLY et al. 2007). A Répce-folyó felső szakaszáról korábban nem volt ismert.

1799. Campanula cervicaria L. - KZD (G): Kozmadombja, Kerkakutas-Kozmadombja erdészeti út menti csarabos szegélyben [9265.1] (MA 2008). RS: Iván, Csapod felé vezető út mentén, cseres-tölgyes szegélyében kevés egyed [8567.2] (MA 2006). GYS: Szombathely, Püspöki-erdő cseres-tölgyes szegélyében néhány tő [8865.2] (SD 2015). - A Kőszegihegységben (KIRÁLY 1996), a Vas-hegyen (BoRBÁs 1887), az Őrségben és Zalában (KÁROLYI et al. 1971) szórványosan fordul elő. Főleg száraz, nyílt erdőszegélyekben él, ezek cserjésedésével, erdősülésével jelentősen visszaszorult.

1801. Campanula bononiensis L. - RS: Dénesfa, Dénesfa-Répceszemere közötti közút menti árokban alacsony példányszámban [8568.3] (MA 2011). RS: Nemeskér, Kardos ér mellett a temetőtől keletre [8566.2] (KG 2007). - A térségben szórványosan megjelenő faj, mely leginkább hegységeinkben (Vas-hegy, Kőszegi-hegység, Soproni-hegység, Ság-hegy, Kissomlyó) fordul elő (KIRÁLY 1996, 2004, MESTERHÁZY et al. 2003). Néhány korábbi jelzése van az Egerszeg-Letenyei dombság területéről (KÁROLYI et al. 1971). Korábbi adatai a Répce-síkról nem voltak ismertek.

1860. Pulicaria vulgaris Gaertn. - AKH: Kemenessömjén, cserjés legelő pocsolyáinak szegélyében [8668.4] (MA 2008); Egervölgy, felhagyott katonai gyakorlótér pocsolyáiban [8867.4] (MA 2006). FKH: Órimagyarósd, a településtől északra lévő földutak keréknyomaiban [9165.1] (MA 2010). RV: Molnaszecsőd, a Csörnöc-patak ártéren „belvizes” szántón néhány tő [8966.3] (SZ 2006). - Jellemzően kötött talajú termőhelyeken, pocsolyák szegélyében megjelenő, iszapnövényzetben élő faj. Korábban a Rábától délre számos helyről gyüjtötték (KÁROLYI et al. 1974), míg attól északra csak több mint 100 éves adata ismert a Kőszegi-hegységben (WAISBECKER 1891).

1922. Artemisia annua L. - AKH: Sárvár-Hegyközség, rekultivált hulladéklerakó felületén [8767.4] (KL 2012). - Nyugat-Ázsiai eredetű adventív faj. Elsősorban bolygatott élőhelyek, ruderális gyomtársulások növénye. A Nyugat-Dunántúlról sem korábbi irodalmi adata, sem gyűjtött herbáriumi lapja nem ismert. A most fellelt előfordulás minden bizonnyal a rekultivációhoz felhasznált talajjal történő behurcolás eredménye.

1944. Senecio sylvaticus L. - AKH: Bejcgyertyános, Farkas-erdő, vágásokban [8867.4] (KL 2011). FKH: Ispánk, a Viszákra haladó erdészeti út mentén vágásban szórványosan [9164.2] (MA 2010). - A térségben szórványosan megjelenő faj. Jellemzően az erdei vágásnövényzet tagja. Az Alsó-Kemenesháton a Farkas-erdőben is ilyen élőhelyről kerül elő.

1945. Senecio viscosus L. - AKH: Bejcgyertyános, Farkas-erdő telepített erdei fenyves szegélyében [8867.4] (KL 2011); Szergény, tufagyürü, kőtörmelékes helyeken [8669.3] (MA 2008). - Az előző fajhoz hasonlóan szintén a vágásnövényzet szórványosan előforduló faja. KIRÁLY $(1996,2004)$ a Kőszegi-hegység és a Soproni-hegység tarvágásaiban gyakori fajként 
említi. A két faj gyakran egy élőhelyen együtt is megjelenhet, mint ahogyan ez a Farkaserdőben is megfigyelhető.

1980. Cirsium eriophorum (L.) Scop. - AKH: Jánosháza, Jánosháza-Kissomlyó közút mentén árokban, alacsony egyedszámban [8868.4] (MA 2005). GYS: Vát, gyakorlótér, törmelék lerakóhely környékén 10-20 egyed [8766.2] (MA 2013). - A legeltetés visszaszorulásával a térségből szinte teljesen eltűnt a faj, melynek korábbi előfordulásait Zalacsány (KÁRolYI et al. 1974), Szombathely (BoRBÁs 1887), Bozsok (KiRÁlY 1996) - nem sikerült megerősíteni. Egyedül Sopron környékén vannak még stabil állományai (KIRÁLY 2004). A Jánosháza melletti állomány az észlelést követő években szintén eltűnt. A Vát térségéből előkerült populáció kisebb fészkű egyedekből áll, mint a tipikus C. eriophorum, illetve attól eltérően a fészekpikkelyeik függelékesek, ez alapján a növény erősen emlékeztet a $C$. boujartii-ra. A fészek azonban annál jóval gyapjasabb, a nyelves virágai és a fészekpikkely függelékei is sötétebbek. $\mathrm{Az}$ itteni egyedek leginkább az Északiközéphegységben elterjedt $C$. eriophorum-okra hasonlítanak. A gyapjas aszat alakköreinek taxonómiai tisztázása még várat magára, ezért egyelőre a váti populációt is a $C$. eriophorum fajhoz tartozónak véljük. Mivel a populáció egy lerakóhely környékére korlátozódik valószínűleg építési törmelékkel együtt hurcolhatták be.

1984. Cirsium brachycephalum Jur. - RTS: Sárvár, 84-es út melletti szántóföld szegélyében [8767.2] (MA 2012). - A 84-es főút sárvári elkerülő szakasza mellett található lefolyástalan, vízállásos területen közvetlenül egy szántóföld szomszédságában került elő egy közel 50 tőből álló állománya. A faj előfordulását a Rábától északra csak BoRBÁs (1887) jelezte Sárvár és Rábasömjén környékéről, de az utóbbi 125 évben itt nem került elő. A közelben Celldömölk és Mersevát mellett a Marcal-medencében a faj stabil állományokkal van jelen. (KULCSÁR \& MESTERHÁZY 2008).

1987. Cirsium pannonicum (L. f.) Link - AKH: Vásárosmiske, Púpos-hegy lejtősztyepjében kis egyedszámú populáció [8768.3] (KL 2011). - Pontusi-pannóniai flóraelemként meglehetősen ritka a Nyugat-Dunántúlon. Aktuális adatai ismertek még a Sopronihegységből (KIRÁLY 2004), a Fertőmelléki dombsorról (KIRÁLY 2001) illetve a cáki gesztenyés oldalról (Kovács \& TAKÁcs 1994).

1999. Centaurea jacea L. subsp. banatica (Rochel) Hayek - PV: Pötréte, tôzegbányatavak menti nedves kaszálóréten számos egyed [9367.2] (MA 2006). - Az újabban alfaji rangon elkülönített taxont korábban csak Zalalövő térségéből említették (KÁROLYI et al. 1974). Az 1800-as évek végén még a Rábától északra Pinkafőnél (ma: Pinkafeld) is gyüjtötték (Simonkai L. 1904, BP-230564). A Pötrétén fellelt populációban számos subsp. jacea habitusú egyed is megtalálható.

2016. Hypochoeris maculata L. - AKH: Vásárosmiske, Púpos-hegy [8768.3] (KL-MA 2007). - JEANPlONG (1983) Szelese, Sajtoskál és Pusztacsalád száraz tölgyeseiből közli, míg a Délnyugat-Dunántúlról korábban a Vendvidékről, Nagykanizsa környékéről és ÉszakZalából jelezték (KÁRoLYI et al. 1975). A dombvidéki régióból származó korábbi adatai közül az Észak-zalaiakon kívül - ahol a szőlőhegyek félszáraz gyepjeiben ma is él (ÓvÁRI M. ex verb.) - korábbi előfordulásait nem sikerült megerősíteni. A Soproni-hegységben a száraz kaszálóréteken (KIRÁLY 2004), míg a Kőszegi-hegységben gesztenyésekben még napjainkban is megvannak alacsony egyedszámú állományai (KIRÁLY 1996), de élőhelyei ezeken a helyeken is veszélyeztetetté váltak. A ligetes cseres-tölgyesek kialakulásában szerepet játszott az erdei legeltetés, melynek felhagyásával ezek az élőhelyek napjainkra nagyrészt megszűntek, így a hozzájuk kötődő fajok - köztük a Hypochoeris maculata jelentősen visszaszorultak.

2055. Crepis taraxacifolia Thuill - ELD: Borsfa, földút szegélyében néhány egyed [9566.2] (MA 2009); Pusztaszentlászló, többéves parlagon tömeges [9367.3] (ÓM-MA 2007). - Hazai előfordulásait a korábbi hazai flóraművek adventívnek tekintik (Soó 1970, SimoN 2000). 
Állományait korábban Dél-Zalából jelezték (KÁROLYI \& Pócs 1954, 1964). Feltehetőleg DélZalában több helyen is előforduló faj, mely az évelő füvek által dominált több éves parlagokon jelenik meg és a gyep záródásával eltűnik. Élőhelyei inváziós fajokkal nem fertőzött, fajgazdag parlagok, ahol a növény beilleszkedik a parlagszukcesszió elemei közé. Annak ellenére, hogy a zalai lelőhelyek a faj elterjedési területének súlypontjától meglehetősen távol esnek, állandó jelenléte és az előfordulások körülményei alapján nem jelenthetjük ki egyértelműen, hogy a térségben adventív. Virágzási idejét a hazai határozókönyvek (SIMON 2000, KIRÁLY 2009) június-augusztus közé teszik. Valójában a növény már májusban virágban van, és így az egyik legkorábban virágzó Crepis fajunk.

2057. Crepis paludosa (L.) Moench - AKH: Sitke, Lánka-patak melletti égeresben [8767.4] (KL 2012). - Égerligetek, láprétek, magaskórósok ritkuló növénye. Aktuális adatai a Kőszegi-hegységből (KIRÁLY 1996), a Soproni-hegységből (KIRÁLY 2004) és a DélnyugatDunántúlról (KÁROLYI et al. 1975) származnak. A faj az Alsó-Kemeneshát területéről korábban nem volt ismert. Térségünkben a fajnak a sitkei a legkeletibb ismert előfordulása.

2129. Stratiotes aloides L. - RV: Csákánydoroszló, a település és a Rába-folyó közötti holtágban több példány [9065.1] (SZ-MA 2011). - Korábbi adata a Nyugat-magyarországi peremvidékről nem volt ismert. Feltehetően a Rába-holtágban történt megtelepedése csak időszakos lehetett, mivel a folyó 2013-as áradása után már nem került elő. Az 1990-es évek végén hasonló típusú megjelenése volt a szentgotthárdi Hársas tavon (AMBRus A. ex verb.), de néhány év múlva innét is eltűnt.

2152. Ornithogalum $\times$ degenianum Polgár - RTS: Uraiúffalu és Nick közötti szántóföld szegélyében [8667.2] (KL 2013). - Nyugat-Dunántúlon ritka taxon. Elsősorban bolygatott helyeken, akácosban, útszéli mezsgyéken fordul elő. Korábban KESZEI (2001) Vasegerszeg és Vámoscsalád határában a Répce-síkról illetve KuLCSÁr (2009) Sitke belterületéről jelezte az előfordulását.

2156. Ornithogalum pannonicum Chaix. - AKH: Celldömölk, Ság hegy, száraz gyepekben szórványos [8768.4] (MA 2008). - A Ság hegy flóráját érintő korábbi munkák (BoRBÁs 1887, MESTERHÁZY et al. 2003) a madártejek közül két fajt (O. kochii, O. umbellatum) jeleznek. Feltehetően az előbbi két faj valamelyikével tévesztették össze az $O$. pannonicumot, ugyanis nehéz elképzelni, hogy a hegyen viszonylag elterjedt, feltűnő fajt korábban ne vették volna észre. Ezt a verziót támasztja alá, hogy a terület növényzetéről készült szakdolgozatban (SEBESTYÉN 1975) a pusztai madártejként közölt fotókon is az üstökös madártej szerepel. A tévesztés ellenére megfigyeléseink szerint mindhárom faj megtalálható a Ság hegyen. Az O. pannonicum a régióban kifejezetten ritka, a közelmúltban találták meg Jákfa térségében (KESZEI 2009).

2182. Allium ursinum L. - AKH: Zalaerdőd, Felső-Újgáti erdőben egy erdészeti út mellett egy kisebb foltban [8968.4] (MA-SD 2008); Egyházashetye, Martonfai-erdő gyertyánostölgyeseiben több nagy kiterjedésű folt [8868.4] (MA 2008). AZV: Ötvös, Kávás-kúti erdőben két kisebb folt [8968.4] (MA 2011). ELD: Alsónemesapáti, jó természetességű bükkösben egy kis folt [9167.1] (MA 2010); Kehidakustány és Barátsziget között mélyút cserjésedő szegélyében [9168.2] (MA 2013). - A Nyugat-Dunántúlon ritka faj, de az utóbbi évtizedben több új helyrôl is előkerült (KIRÁLY et al. 2007, MESTERHÁZY 2013). A fent jelzett adatok közül a zalaerdődit és az ötvösit Szodfridt István már az 1970-es években megtalálta és levélbeli közlése alapján KEVEY (1978) publikálta. A lelőhelyeket sokáig eredménytelenül kerestük, de a területen folyó intenzív erdőgazdálkodás degradáló hatása ellenére a faj néhány kisebb foltban végül előkerült. A faj többi, most közölt adata korábban nem került publikálásra. Új adatai florisztikailag kevésbé feltárt területekről származnak, így az előfordulások számának növekedéséből nem következtethetünk a faj expanziójára.

2224. Gagea minima (L.) Ker Gawl. - AKH: Bejcgyertyános, Farkas-erdőben a Mária Terézia kút melletti erdőrészben [8867.4] (KL 2012). - A Nyugat-Dunántúlon csak régi 
irodalmi adatokkal rendelkező faj. BoRBÁs (1887) Tótfalu (ma Sorkikápolna), Pócs (1954) Nagykanizsa, KÁROLYI \& Pócs (1964) Homokkomárom helymegjelöléssel közölte a faj előfordulását. Az utóbbi 50 évben a térségből nem volt aktuális adata. A MTM Növénytárban a Szombathely környéki (Sé, Boros Á. 1922, BP-412185) gyertyános tölgyesekből is van régi gyüjtése.

2287. Luzula pallidula Kirschner - AKH: Magyargencs, cseres-tölgyesben [8569.4] (MA 2010). - Aktuális lelőhelye a Nyugat-Dunántúlon csupán néhány ponton ismert (KIRÁLY et al. 2007), míg a Kemenesháton korábban nem volt adata. A Kemenesháton a legtöbb lehetséges élőhelyét akáccal és erdei fenyővel újították fel, így napjainkra már kevés az olyan jó állapotú acidofil cseres-tölgyes, ahol a faj potenciálisan megtelepedhetne.

2346. Catabrosa aquatica (L.) P. Beauv. - AKH: Sitke, Lánka-patak melletti égeresben és a közeli mesterséges tó szegélyében [8767.4] (KL 2012). - A Nyugat-Dunántúlon ritka fajnak aktuális előfordulási adatait KIRÁLY et al. (2007) ismertetik. Hasonló, jó természetességű, szivárgóvizes égerligetekben találjuk a fajt Dél-Zalában, míg a Kisalföldön leginkább szabályozott, árnyaló növényzettől megfosztott kisebb patakok szegélyében él. A fajnak az Alsó-Kemeneshátról nem ismert korábbi adata.

2393. Elymus caninus (L.) L. - RV: Csákánydoroszló, Rába-zátony [9064.4] (MA 2006); Sárvár, Szatmár-erdő [8767.2] (KL 2011). - A Nyugat-Dunántúlon szórványosan megjelenő, keményfaligetekben, üde gyertyános-tölgyesekben élő faj. A térségből irodalmi adatokból ismert Velem (KovÁCS et al. 1992), a Gyöngyös-patak (GondolA 1965) és Nagykanizsa (KovÁcs 2005) környékéről. A most fellelt mindkét állomány a Rába-völgyében található.

2429. Koeleria pyramidata (Lam.) P.Beauv. - AKH: Kemenessömjén, cserjésedő legelőn [8668.4] (MA-KL 2013). - A faj magyarországi előfordulását SzodFRIDT \& TALLós (1966) közli először a Felsőnyírádi-erdőből, ahol napjainkban is megtalálható. Később sorokpolányi adatát publikálja KIRÁLY \& MESTERHÁZY (2006) megjegyezve, hogy az adat felülvizsgálatra szorul. A kérdéses növényt később teljes fejlettségi állapotában megvizsgáltuk és megállapítottuk, hogy az a Koeleria cristata-hoz tartozik. A Koeleria pyramidata az Alsó-Kemeneshát Marcal-medencével érintkező részéről került elő, ahol egykoron a változó vízhatású cseres-tölgyesek voltak jellemzőek. Ezeket napjainkra szinte teljesen kiirtották, helyükön gyakran fás legelők vagy legelők létesültek. A növény egy ilyen enyhén legeltetett, cserjésedő gyepből került elő, ahol a fényperje mellett más cserestölgyes fajok is (Potentilla alba, Ranunculus illyricus, Lychnis viscaria) fennmaradtak.

2537. Sparganium erectum L. subsp. microcarpum (Neuman) Domin - VH: Felsőcsatár, patak szegélyében [8764.4] (MA 2009). FKH: Viszák, patak szegélyében [9164.2] (MA 2010). - Soó (1980) csak néhány adatát említi az országból, Nyugat-Magyarországról ezek közül csak Kőszegszerdahely helymegjelöléssel hozza. Ritkasága nehéz felismerhetőségén alapszik, valószínűleg a régióban (és az országban is) jóval elterjedtebb lehet. Azonosítását nehezíti, hogy a határozókönyvek fő elkülönítő bélyegeként a termés alsó részének nyélbe keskenyedését említik, ami friss növényen egyáltalán nem szembetűnő, így a terepi határozás során nem alkalmazható. Határozásnál fontosabb a szár és az allevelek tövének vizsgálata, ugyanis a többi alfajnak az rózsaszínes futtatású, míg a subsp. microcarpum-nak egyöntetűen fehér. Ez a bélyeg azonban csak a populáció egészének vizsgálata során alkalmazható, mivel a subsp. neglectum-nál is lehet néha fehér a szár és az allevelek töve.

2556. Bolboschoenus maritimus (L.) Palla - AKH: Vashosszúfalu, Ódorfai téglagyári tó szegélyében [8868.3] (MA-KB 2005). RS: Csér, téglagyári tó szegélyében [8567.4] (MA 2003); Völcsej, a település nyugati szélén, bányató szegélyében [8566.2] (MA 2008); Sitke, Lánka-patak melletti mesterséges tó szegélyében [8767.4] (MA-KL 2013). GYS: Kôszegfalva, Abért-tó szegélyében [8665.1] (MA 2013) ugyanitt KESZEI (2013).

2557. Bolboschoenus planiculmis (F.Schmidt) T.V. Egorova - RS: Vámoscsalád, a 84-es úttól északra belvizes foltban [8667.2] (MA 2011), ugyanitt KEszeI (1998); Csáfordjánosfa, 
Répceszemere felé az út mellett belvizes foltban [8567.4] (MA 2012); Mesterháza, Tompaládony felé a műúttól délre belvizes szántón [8667.1] (MA 2014); Tompaládony, Nagygeresd felé vezető út mellett belvizes szántón [8667.1] (MA 2014); Iván, Csáfordjánosfa felé vezető úttól északra belvizes foltban [8567.4] (MA 2012). RTS: Szeleste, Kőris-patak mentén belvizes szántón [8667.3] (MA 2012). RV: Körmend, Dobogó-erdő szomszédságában belvizes szántón [9065.1] (MA-SZ 2011).

2558. Bolboschoenus glaucus (Lam.) S.G.Sm. - GYS: Szombathely, Csónakázó-tó szegélyében [8765.4] (MA 2014). RV: Alsószölnök, az erőmű közelében belvizes szántón [9063.3] (MA 2011); Répcelak, a 86-os úttól délre belvizes szántón [8568.3] (MA 2014). HROUDOVÁ et al. (2007) a Bolboschoenus nemzetség fajainak európai összefoglaló munkájában szerepelnek a MTM Növénytárában a szerzők által revideált gyűjtések. A cikkben Nyugat-Magyarország térségéből nem találhatók adatok, ugyanis innét nem volt egyik fajnak sem gyüjtése. A zsióka-fajok elterjedésének tisztázása végett közöljük a térségben előforduló taxonok lelőhelyeit. Korábban BoRBÁs (1887) Kőszeg és Körmend térségéből közölt adatokat, KovÁcs (2005) Zala megye néhány pontjáról, illetve KESZEI (1998) Vámoscsalád mellől társulásalkotóként publikálta. Újabban KESZEI (2013) jelezte a Kőszegfalva mellett lévő Abért-tóból. Az összes ismert adat korábban B. maritimus néven került publikálásra.

2589. Carex davalliana Sm. - SM: Sopron, Ikva-menti réten néhány tő [8265.3] KL (2012). Az országosan is ritka fajnak Sopron környékén csak néhány állománya ismert (KIRÁLY 2004). Újabban előkerült Ebergőc határában az Ikva-síkon is (KIRÁLY et al. 2007). A soproni Ikva-menti rétről („Zeiselwiesen”) a korábbi irodalmi források nem jelezték.

2596. Carex elongata L. - AKH: Sitke, Lánka-patak melletti égeresben és a közeli mesterséges tó partján [8767.4] (KL 2012). - Láprétek, égeresek ritka növénye. PAUER (1932) a vasvári Szentkút melletti égeresből közli. Jeanplong József 1938-ban a bozsoki Felső-lápréten gyűjtötte (BALOG \& KULCSÁR 2013). Kőszeghegyalján a kőszegi tőzegmohás lápokon állományalkotó (KIRÁLY et al. 2007). Az Örségben és Zalában még számos aktuális lelőhelye ismert. A térségünkben észak-keleti irányban a most előkerült sitkei előfordulás a legszélső. Az Alsó-Kemeneshátról korábban nem jelezték.

2602. Carex otrubae Podp. - ZH: Nagykanizsa, Kiskanizsa csatornaszegélyben szórványos [9567.2] (MA 2011). RS: Répceszentgyörgy, „Muzsaj” mesterséges tó szegélyében kevés egyed [8667.1] (MA 2013); Völcsej, a település déli szomszédságban lévő nedves réten [8566.2] (KG 2007); Vitnyéd, a településtől délkeletre lévő kavicsbányatavak szegélyében [8467.2] (KG 2012). SM: Sopron, Sós-patak mente [8265.3] (KG 2007). - A Kisalföldön szórványos fajnak a Nyugat-Dunántúlon nagyon kevés irodalmi adata ismert. A Kőszegihegység pereméről WAISBECKER $(1891,1895)$ és újabban KESZEI et al. (1999) jelzik, míg néhány adata Dél-Zalából származik. A most közölt kiskanizsai előfordulás KÁROLYI \& Pócs (1954) sormási adatának megerősítése. Valószínűleg a Rábától északra elterjedtebb a faj, de a Carex vulpina-hoz való hasonlósága folytán ritkán veszik észre.

2606. Carex disticha Huds. - RS: Répceszentgyörgy, „Muzsaj” régi lecsapoló árok szegélyében [8667.1] (MA 2013). GYS: Ölbő, „Bogár-tó” néhány négyzetméteres folt [8767.1] (KL 2015). - A térségből régi adatai ismertek Sorkifaludról (BoRBÁs 1887) és Kőszeg környékéről (WAISBECKER 1882). Aktuálisan csak a Soproni-hegységből (KIRÁLY 2004) és Sitke mellől (KuLCSÁR 2004) ismert. A korábbi Rába mentén jelzett előfordulása (RABóCZY 1939) a Savaria Múzeumban lévő herbáriumi példány vizsgálata alapján a Carex repens-nek bizonyult (MESTERHÁZY \& KIRÁLY 2006). A Répce-síkkal szomszédos Csornaisíkon ritka (SCHMIDT 2010), míg a Marcal-medence magassásosaiban, mocsárrétjein gyakori fajnak számít (MESTERHÁZY ined.).

2614. Carex cespitosa L. - FKH: Öriszentpéter, Bárkás-tó zsombéksásos állományában néhány tő [9164.2] (MA 2008); Hegyhátszentjakab, a szennyvíztelep közelében lévő 
felhagyott réten néhány tő [9165.1] (MA 2006); Szalafó, Felsőszer, Zala-patak menti nedves réten számos egyed [9163.2] (MA 2008). - Korábban az Őrségből csak a szlovén határ mellől jelezték (SzODFRIDT \& TALLós 1965). Általában együtt fordul elő a Carex elata-val, mellyel könnyen összetéveszthető. Érdekes, hogy a faj Szlovéniából nem ismert (JIMENEZMEIJAS et al. 2014), pedig a most megtalált állományok a határ közelében vannak. NyugatMagyarországon az őrségi előfordulásokon kívül csak Kőszeg mellett ismert (VIDÉKI \& HUSZÁR 2002).

2623. Carex digitata L. - AKH: Sárvár, Városi-erdőben szórványos [8767.4] (KL 2012). - Az Alsó-Kemeneshát nyugati meredek letörésén az egykori bükkelegyes gyertyános tölgyes erdő aljnövényzetének maradvány növénye a Carex pilosa-val együtt. Az AlsóKemeneshátról korábban nem jelezték a faj előfordulását. A közelben hasonló élőhelyen a vasvári Szentkút melletti erdőben - a Felső-Kemeneshát területén - is megtalálható (JEANPLONG 1999).

2627. Carex fritschii Waisb. - FKH: Nádasd, Nádasdi-erdő ligetes cseres-tölgyesében ritka [9065.4] (MA 2010). AKH: Bejcgyertyános, Farkas-erdő bükkös szegélyben [8867.2] (MA 2012). - A faj aktuális nyugat-magyarországi elterjedését KIRÁLY et al. (2007) részletezi. Az Őrségből csak régi adatok ismertek Hegyhátsálról (JÁVORKA 1940) valamint Szőcéről (Pócs et al. 1958). Az újonnan megtalált állomány egy régi legelőerdő maradványában van a Nádasdi-fennsíkon. A lefolyástalan területen korábban nagy kiterjedésű legelőerdők voltak, melyek a tájhasználat változásával beerdősültek vagy helyükön fenyőültetvényeket hoztak létre. Mindkét folyamat hozzájárult a dunántúli sás visszaszorulásához.

2640. Carex rostrata Stokes - FKH: Hegyhátszentjakab, a Vadása-tó ülepítőtavában több nagyobb folt [9165.1] (MA 2005). - Zala megye és az Őrség láprétjeiről is több korábbi adata ismert (KÁROLYI \& Pócs 1954, 1964), ezeket újabban a szőcei (LÁjER 1997) előfordulás kivételével nem sikerült megerősíteni. Termőhelyének vízháztartására rendkívül érzékeny, általában jó állapotú, üde láprétek növénye. Ennek fényében meglepőnek tûnik a faj megjelenése víztározó ülepítő tavában, bár a közelmúltban Zala megyében is előkerült hasonló élőhelyről (ÓvÁRI ex verb.).

2642. Carex melanostachya Willd. - RTS: Szeleste, Váti-erdő vízállásának szegélyében szórványos [8766.2] (MA 2008). RS: Mesterháza „NNagy-árok” szegélyében egy nagyobb folt [8667.1] (MA 2013). - Aktuális adatai a Répce-síkról ismertek (KIRÁlY et al. 2007). A szelestei előfordulás azoktól nemcsak tájföldrajzilag, hanem az élőhely szempontjából is eltér, ugyanis nem „alföldi” környezetben, hanem változó vízhatású termőhelyen lévő cseres-tölgyes vizes mélyedésének szegélyében található meg.

2655. Carex hostiana DC. - AKH: Sitke, Lánka-patak mellett üde lápréten [8767.4] (KL 2013). - Nyugat-Dunántúl meszes talajú, üde láprétjeinek ritka faja, aktuális előfordulásai leginkább Zala megyére esnek (KovÁcs 2005). Az Alsó-Kemeneshátról nem volt korábban adata, de a közeli Marcal-medencében Adorjánházánál (MESTERHÁZY ined.), illetve Sitke és Vásárosmiske között elterülő lápréten megtalálható (KULCSÁR 2004).

--- Carex randalpina B. Wallnöfer - MBS: Fityeház, a falutól délre égeresedő magassásosban állományalkotó [9667.1] (MA 2014). - Az Alpokban és annak előterében élő, szűk elterjedésű faj első hazai észleléséről MESTERHÁZY et al. (2011) adnak tájékoztatást. Előfordulása Magyarországon a Göcsej és az Egerszeg-Letenyei-dombság területére koncentrálódik. A faj elterjedési területén nálunk található meg a legalacsonyabb tengerszint feletti magasságban. A fityeházi lelőhelye nemcsak azért érdekes, mert az eddigi hazai észlelésektől eltérően a Mura-balparti-síkon található, hanem mert ez az eddigi legalacsonyabban fekvő észlelés (132 m tszf.).

2676. Cephalanthera damasonium (Mill.) Druce - AKH: Káld, Farkas-erdő [8867.2] (KL 2012); Sitke, alginit bánya melletti erdőben [8768.3] (KL 2013). - A Nyugat-Dunántúlon kifejezetten ritka kosbor (MoLNÁR V. 2011). Aktuális adatait a Kőszegi-hegységből és a 
Soproni-hegységből, Ikva-síkról és a Fertőmelléki-dombsorról ismerjük. Az AlsóKemenesháton előfordulását korábban nem jelezték. A közelben a Sitke melletti Hercseghegyen ismert még egy kisebb populációja (KULCSÁR \& MESTERHÁZY 2008).

2683. Spiranthes spiralis (L.) Chevall. - AKH: Kemenessömjén, a településtől északra száraz gyepben [8768.2] (MA-KL 2013). FZV: Zalalövő, kaszálógyümölcsösben kb. 500 tő [9165.4] (GÁ 2013). - A faj előfordulásai a térségünkben elsősorban a DélnyugatDunántúlra - Őrség, Vendvidék, Zalai-dombvidék - esnek (MoLnÁR V. 2011). Az AlsóKemeneshát területén mindössze egy adata volt ismert a Kenyeri reptéren (Víg et al. 2006). Kemenessömjén határában felhagyott gyümölcsös gyepjében került elő 10-20 töves állománya. Kiemelendő a zalalövői előfordulás nagy egyedszámával illetve, hogy a növény termőhelyét jelentő kaszálógyümölcsös a település belterületéhez tartozik (GRUBER ex verb.).

2693. Dactylorhiza incarnata (L.) Soó. - AKH: Sitke, Lánka-patak melletti lápréten 10 virágzó tő [8767.4] (KL 2012). - A Nyugat-Dunántúlon ritka kosbor (MoLNÁR V. 2011). Aktuális adatait a térségből KIRÁLY et al. (2007) ismertetik. A közelben még Sitke határában, a Cinca-patak melletti lápréten él egy erős, százas egyedszámú állománya (KULCSÁR 2004). Az Alsó-Kemeneshátról korábban nem jelezték az előfordulását.

2694. Dactylorhiza majalis (Rchb.) P.F. Hunt et Summerh. - AKH: Sitke, Lánka-patak melletti lápréten [8767.4] (KL 2012). - A Lánka-patak melletti láprét foltban találtuk 2012 májusában 5 virágzó tövét. A faj jellemző nyugat-dunántúli előfordulásai főként az Őrség, a Vendvidék, a Kőszeghegyalja és a Zalai-dombvidék területére esnek (MoLNÁR V. 2011). Az Alsó-Kemeneshátról korábban nem jelezték. A közelben Sitke mellett a Cinca-patak láprétjén ismert még egy állománya (KULCSÁR 2004).

2697. Dactylorhiza fuchsii (Druce) Soó - FKH: Szőce, Nádasdi-erdő fenyőelegyes-tölgyes erdőszegélyében néhány tő [9065.3] (SZZS 2010). - Területünkön szórványos és rapszodikus megjelenésű faj. Lelőhelyeit korábban a Vendvidékről és a Hetésből jelezték (KÁROLYI \& PóCS 1954, TíMÁR 1995). Figyelemre méltó adatokat közölt JEANPLONG (1983), aki Szeleste és Vitnyéd környékén „lápos helyeken” találta. Aktuálisan Zala megyéből, a Kőszegi- és a Soproni-hegységből ismerjük előfordulásait (MoLNÁR V. 2011).

2704. Orchis purpurea Huds. - GYS: Csénye, Tilos-erdőben néhány tő [8767.3] (KL 2014). Az országosan egyik leggyakoribb kosbor a Nyugat-Dunántúlon meglehetősen ritka. A Fertőmelléki-dombsor területén (KIRÁLY 2001), a Kőszegi-hegységben (KIRÁLY 1996) és a Zalai-dombvidéken (FARKAS 1999) ismertek aktuális előfordulásai. Korábban GÁYER (1925) és Soó (1934) Szeleste helymegjelöléssel jelezte. GÁYER (1929) a gércei Nemes-hegyről és a sitkei Hercseg-hegyről, JEANPLONG (1972) a sárvári és a csényei Tilos-erdőből közölte az előfordulását. Az irodalomban jelzett állományokat a csényei kivételével nem sikerült újonnan megtalálni.

\section{Köszönetnyilvánítás}

Köszönetünket szeretnénk kifejezni Gruber Ágnesnek, Farkas Sándornak, Keszei Balázsnak, Király Gergelynek, Lelkes Andrásnak, Óvári Miklósnak, Schmidt Dávidnak, Schubert Zoltánnak és Szekeres Zsófiának, hogy közöletlen adataikat rendelkezésünkre bocsájtották. Balogh Lajosnak, Barina Zoltánnak és Pifkó Dánielnek a herbáriumi adatgyűjtés segítéséért illeti köszönet.

Köszönjük továbbá Király Gergelynek, Schmidt Dávidnak és Szépligeti Mátyásnak a kézirathoz füzött értékes és jobbító szándékú megjegyzéseiket. 


\section{Irodalom}

BAKAN B. (2006): Slikovni pregled višjih rastlin Prekmurja. - Razvojni center, Lendava, 245 pp.

BALOGH L. \& KuLCSÁR L. (2013): Jeanplong József herbáriuma a szombathelyi Savaria Múzeumban. Savaria: a Vas Megyei Múzeumok Értesítője 36: 23-51.

BALOGH L., DANCZA I. \& KIRÁLY G. (2004): A magyarországi neofitonok időszerű jegyzéke és besorolásuk inváziós szempontból. - In: MıнÁLY B. \& BotTA-DuKáT Z. (szerk.), Biológiai Inváziók Magyarországon. Özönnövények. TermészetBúvár Alapítvány Kiadó, Budapest, 61-92.

Bodonczi L. (1999): Az Őrség és Vendvidék védett és veszélyeztetett növényei. - Kitaibelia 4: 169-177.

Bodonczi L. (2002): Újabb adatok Vas megye flórájához. - Kitaibelia 7: 157-161.

Borbás V. (1887): Vasvármegye növényföldrajza és flórája. - Vas Megyei Gazdasági Egyesület, Szombathely, $391 \mathrm{pp}$.

CSAPODY I. (1953): Új növényelőfordulások Sopron környékén és Baranyában. - Erdőmérnöki Főiskola Évkönyve („1951/52”), pp. 17-21.

Csiky J. (2004): A Karancs, a Medves-vidék és a Cerová Vrchovina (Nógrád-Gömöri bazaltvidék) flóra- és vegetációtérképezése. - Szerzői kiadás, Pécs, 451 pp.

DöVÉNYI Z. (szerk.) (2010): Magyarország kistájainak katasztere. - MTA Földrajztudományi Kutatóintézet, Budapest, 876 pp.

FARKAS S. (szerk.) (1999): Magyarország védett növényei. - Mezőgazda Kiadó, Budapest, 416 pp.

FISCHER \& NikLFELD (2008): Floristiche Neufunde (76-98). - Neilreichia 5: 263-288.

FREH A. (1883): Kőszeg és vidékének viránya. - Kőszegi Katholikus Gimnázium Értesítője („1882/83”), pp. 3-63.

GÁYER Gy. (1932): Új adatok Vasvármegye flórájához III. [Neue Beiträge zur Flora des Komitates Vas (Eisenburg) III.] - Annales Sabarienses Folia Musealia 1: 7-11.

GÁYER Gy. (1913): Adatok Vasvármegye flórájához [Addiamenta ad floram comit. Vas]. - Magyar Botanikai Lapok 12: 312-313.

GÁYER GY. (1925): Vasvármegye fejlődéstörténeti növényföldrajza és a praenorikumi flórasáv. Vasvármegyei Múzeum Évkönyve 1: 1-43.

GÁYER Gy. (1927): Neue Beiträge zur Flora des Komitates Vas (Eisenburg). - Vasvár-megye és Szombathely város Kultúregyesülete és a Vasvármegyei Múzeum Évkönyve 2: 248-255.

GÁYER Gy. (1929): Új adatok Vasvármegye flórájához II. - Vasvármegyei Múzeum Évkönyve 1927-29. 3: 71-75.

Gомвосz E. (1906): Sopron vármegye növényföldrajza és flórája. - Mathematikai és Természettudományi Értesítő 28: 401-577.

Gondola I. (1965): Az Impatiens gladulifera Royle terjedése a Nyugat-Dunántúl vízparti növénytársulásaiban. - Botanikai Közlemények 52: 35-46.

HÉJJAS I. \& BoRHIDi A. (1960): Csurgó és környéke flórája. - Botanikai Közlemények 48: 245-256.

HoRvÁth E. \& JEANPLONG J. (1962): Vas megye ritka és védelmet érdemlő növényei. - Savaria Múzeum Közleményei 18: 19-43.

HoRvÁth E. (1978): Természeti viszonyok. - In: HoRváth F. (szerk.), Sárvár monográfiája. Sárvár Város Tanácsa, Szombathely, pp. 7-44.

Hroudová Z., ZÁkravsky P., DucháčEK M. \& Marhold K. (2007): Taxonomy, distribution and ecology of Bolboschoenus in Europe. - Annales Botanici Fennici 44: 81-102.

JÁvoRKA S. (1940): A Carex fritschii WAISB.-ről. - Acta Geobotanica Hungarica 3: 148-150.

JEANPLONG J. (1956): Flóraelemek szerepe a flórahatárok megvonásában Északnyugat-Dunántúlon. Botanikai Közlemények 46: 261-266.

JEANPLONG J. (1972): Új adatok Északnyugat-Dunántúl flórájának ismeretéhez. - Vasi Szemle 26: 586588.

JEANPLONG J. (1983): Új adatok Északnyugat-Dunántúl flórájának ismeretéhez II. - Vasi Szemle 37: 111114.

JEANPLONG J. (1999): Új adatok Északnyugat-Dunántúl flórájának ismeretéhez IV. - Vasi Szemle 53: 143145.

Jimenez-Meijas P., Hilpold A., Frajman B., Pușcaș M., Koopman J., Mesterházy A., Grulich V., Lye K.A., \& Martin-Bravo S. (2014): Carex cespitosa: reappraisal of its distribution in Europe. - Willdenowia 44: 327-343. 
KÁRolYi Á. \& Pócs T. (1954): Adatok Délnyugat-Dunántúl növényföldrajzához. - Botanikai Közlemények 45: 257-267.

KÁROLYI Á. \& Pócs T. (1957): Újabb adatok Délnyugat-Dunántúl flórájához. - Annales Historico-naturales Musei Nationalis Hungarici 8: 197-204.

KÁRolyi Á. \& Pócs T. (1964): Újabb adatok Délnyugat-Dunántúl flórájához III. - Savaria. A Vas Megyei Múzeumok Értesítője 2: 43-54.

KÁRolyi Á. \& Pócs T. (1968): Délnyugat-Dunántúl flórája I. - Acta Academiae Paedagogicae Agriensis 6: 329-390.

KÁRolyi Á. \& Pócs T. (1969): Délnyugat-Dunántúl flórája II. - Acta Academiae Paedagogicae Agriensis 7: 329-377.

KÁRolyi Á., Pócs T. \& BAlogh M. (1971): Délnyugat-Dunántúl flórája IV. - Acta Academiae Paedagogicae Agriensis 9. 387-409.

KÁRolyi Á., Pócs T. \& BALOGh M. (1972): Délnyugat-Dunántúl flórája V. - Acta Academiae Paedagogicae Agriensis 10: 373-400.

KÁRolyi Á., Pócs T. \& BAlogh M. (1974): Délnyugat-Dunántúl flórája VI. - Acta Academiae Paedagogicae Agriensis 12: 451-463.

KÁRolyi Á., Pócs T. \& BAlogh M. (1975): Délnyugat-Dunántúl flórája VII. - Acta Academiae Paedagogicae Agriensis 13: 395-415.

KÁRPÁTI Z. (1949): Érdekes és újabb növényelőfordulások Sopron környékén. - Erdészeti Kísérletek 49: 168-182.

KESZEI B. (1997): A Répce menti rétek vegetációja Vámoscsalád és Csáfordjánosfa térségében. - Vasi Szemle 51: 469-480.

KESZEI B. (1998): Új növénytársulás Vas megyében. - Vasi Szemle 52: 269-277.

KESZEI B. (2000a): Az Iván környéki szikes foltok növényzete. - Kanitzia 8: 13-18.

Keszei B. (2000b): Újabb adatok a Répce-sík és észak Vas megye flórájának ismeretéhez - Cinege, Vasi Madártani Tájékoztató 5: 39-41.

Keszei B. (2001): Degen-madártej (Ornithogalum × degenianum) Vas megyében. - Cinege, Vasi Madártani Tájékoztató 6: 40-41.

KeSzEi B. (2009): A jákfai Bikamegye rét és védett növényei. - Vasi Szemle 63: 190-203.

Keszei B. (2013): A kőszegfalvi Abért-tó növényélete. - Cinege, Vasi Madártani Tájékoztató 18: 54-59.

KESZEI B., KiRÁLY G. \& KuLCSÁR L. (1999): Újabb adatok Kőszeg környékének edényes flórájához. - Vasi Szemle 53: 335-340.

Kevey B. (1978): Az Allium ursinum L. magyarországi elterjedése. - Botanikai Közlemények 65: 165-175.

Kevey B. (2015): Adatok Magyarország flórájának és vegetációjának ismeretéhez X. - Botanikai Közlemények 102: 39-60.

Kevey B. \& Pozsonyi K. (2003): A Digitalis lanata Erhr. Magyarországi elterjedése. - Kitaibelia 8: 117-131.

KIRÁLY G. (1996): A Kőszegi-hegység edényes flórája. - Tilia 3: 1-415.

KIRÁLY G. (2001): A Fertőmelléki-dombsor vegetációja. - Tilia 10: 181-303.

KIRÁLY G. (szerk.) (2004): A Soproni-hegység edényes flórája. - Flora Pannonica 2: 1-507.

KIRÁLY G. (szerk.) (2009): Új magyar füvészkönyv. Magyarország hajtásos növényei. Határozókulcsok. Aggteleki Nemzeti Park Igazgatóság, Jósvafő, 616 pp.

Király G., Barina Z., HoRváth T. \& MesterháZy A. (2005): Az Orobanche pancicii BeCK előfordulása Magyarországon. - Flora Pannonica 3: 17-26.

Király G., Bartha D., Bodonczi L., KovÁcs J. A., Ódor P. \& TímÁr G. (2002): Az Őrségi Tájvédelmi Körzet védett és veszélyeztetett edényes növényei. - Kanitzia 10: 61-108.

KiRÁLY G. \& MESTERHÁzY A. (2006): Két különleges értékű erdő felfedezése Vas megyében - Kitaibelia 11: 59.

KirÁly G., MesterháZy A. \& KirÁLy A. (2007): Adatok a Nyugat-Dunántúl flórájához. - Flora Pannonica 5: 3-68.

KirÁLY G., NAGY A. \& KiRÁLY A. (2005): Kiegészítések a Soproni-hegység és a Soproni-medence flórájának ismeretéhez. - Flora Pannonica 3: 41-48.

KIRÁLY G. et al. (2003): A magyarországi flóratérképezés módszertani alapjai. - Flora Pannonica 1: 3-20.

KovÁcs D. (2014): Adatok Magyarország flórájához I. - Kitaibelia 19: 254-259.

KovÁcs J. A. (1996): Vas megye flórájának biológiai adatbázisa. Kézirat.

KovÁcs J. A. (2005): Délnyugat-Dunántúl flórája VIII. (Egyszikúek) Károlyi Árpád florisztikai cédulakatalógusa alapján. - Kanitzia 13: 125-275.

KovÁcs J. A. \& TAKÁCS B. (1994): A cáki gesztenyés oldal edényes flórája és növényzete. - Kanitzia 2: 9-42. 
KovÁCS J. A. \& TAKÁCS B. (1998): Az alszószölnöki Rába-vögy botanikai értékei. - Kanitzia 6: 89-110.

KovÁcs J. A., TAKÁcs B. \& VARGA T. (1992): A Köszegi-hegység rétjei. - Berzsenyi Dániel Tanárképző Főiskola, Szombathely, kézirat, 22 pp.

KovÁCS J. A., BoDONCZI L. \& BALOGH L. (2000): A Nemzeti Park létrehozásakor csatolásra javasolt területek I. A (Felső-) Rába-völgy. - In: BARTHA D. (szerk.), A tervezett Őrség-Rába Nemzeti Parkot megalapozó botanikai-zoológiai kutatások VIII. NyME, Sopron, kutatási jelentés, kézirat, pp. 578-601.

KULCSÁR L. (2004): A sitkei láp- és mocsárrétek vegetációja. - Kanitzia 12: 151-176.

KULCSÁR L. (2009): Florisztikai adatok Sárvár környékéről II. - Praenorica Folia historico-naturalia 11: 5-11.

KulCSÁR L. \& MESTERHÁzy A. (2008): Sárvár és Celldömölk környékének védett növényei. - Honismereti Híradó Sárvár 26: 3-49.

LÁJER K. (1997): Az északi sás Vas megyében. - Vasi Szemle 51: 481-491.

LÁJER K. (2005): Magyarország ezüstperjés gyepjei. - Kanitzia 13: 29-43.

MASSON R. \& KADEREIT G. (2013): Phylogeny of Polycnemoideae (Amaranthaceae): Implications forbiogeography, character evolution and taxonomy. - Taxon 62: 100-111.

Mesterházy A. (2007): Polycnemum heuffelii LÁNG előfordulása a Nyugat-Dunántúlon. - Flora Pannonica 5: 196.

MESTERHÁZY A. (2013): A Rába-völgyi erdők élőhelyeinek és lágyszárú fajainak vizsgálata. - Tilia 17: 1-237.

MESTERHÁZy A., BAUER N. \& KulCSÁR L. (2003): A kisalföldi bazalt tanúhegyek edényes flórája. - Tilia 11: $7-165$.

MESTERHÁZy A. \& KiRÁLY G. (2006): A Carex repens BeLLARDi Magyarországon. - Flora Pannonica 4: 99-110.

MESTERHÁZY A., KiRÁly G. \& WALLNÖFER B. (2011): On the occurrence of Carex randalpina B. WALLNÖFER (Cyperaceae) in Hungary. - Annalen des Naturhistorischen Museums in Wien, B 112: 177-180.

MolNÁR V. A. (szerk.) (2011): Magyarország orchideáinak atlasza. - Kossuth Kiadó, Budapest, 504 pp.

PAPP J. (1954): A Lotus uliginosus Magyarországon és néhány új florisztikai adat. - Botanikai Közlemények 45: 267-271.

PAuER A. (1932): Vas vármegye természeti emlékei. - In: Szent Norbert Premontrei Gimnázium 19311932 évi Értesítője. Szombathely, pp. 1-66.

Pinke Gy., PÁl R., Mesterházy A., KirÁly G., Szendrődi V., Schmidt D., Ughy P. \& Schmidmajer Á. (2005): Adatok a Dunántúli-középhegység és a Nyugat-magyarországi peremvidék gyomflórájának ismeretéhez II. - Kitaibelia 10: 154-185.

Pinke Gy., Schmidt D., Schmidmajer Á., KirÁLy G., \& UGhy P. (2003): Adatok a Dunántúli-középhegység és a Nyugat-magyarországi peremvidék gyomflórájának ismeretéhez I. - Kitaibelia 8: 161-184.

Pócs T., Domokos-NAgy É., Pócs-Gelencsér I. \& VIDA G. (1958): Vegetations-studien in Ôrség. - Akadémiai Kiadó, Budapest, $124 \mathrm{pp}$.

PolGÁR S. (1941): Győrmegye flórája (Flora Comitatus Jaurinensis). - Botanikai Közlemények 38: 201352.

RABóczY J. (1939): Vasvármegye flórája. - Debreceni Tudományegyetem, Kézirat.

ScHмidT D. (2010): Adatok a Kisalföld flórájának ismeretéhez II. - Botanikai Közlemények 97: 79-95.

Sebestyén J. (1975): A Ság-hegy növényzete. - Berzsenyi Dániel Tanárképző Főiskola, Szombathely, Szakdolgozat.

Simon T. (2000): A magyarországi edényes flóra határozója. - Tankönyvkiadó, Budapest, 976 pp.

Soó R. (1934): Vasmegye szociológiai és florisztikai növényföldrajzához. - Vasi Szemle 1: 105-134.

Soó R. (1966): A magyar flóra és vegetáció rendszertani-növényföldrajzi kézikönyve 2. - Akadémia Kiadó, Budapest, $655 \mathrm{pp}$.

Soó R. (1970): A magyar flóra és vegetáció rendszertani-növényföldrajzi kézikönyve 4. - Akadémia Kiadó, Budapest, $614 \mathrm{pp}$.

Soó R. (1980): A magyar flóra és vegetáció rendszertani-növényföldrajzi kézikönyve 6. - Akadémia Kiadó, Budapest, $556 \mathrm{pp}$.

Soó R. (1985): A magyar flóra és vegetáció rendszertani-növényföldrajzi kézikönyve 7. - Akadémia Kiadó, Budapest, $682 \mathrm{pp}$.

SzodFridT I. \& TALLóS P. (1965): Újabb adatok a Dunántúl flórájához. - Botanikai Közlemények 52: 23-28.

Szodfridt I. \& TAlLós P. (1966): A Koeleria pyramidata (Lam.) Domin Magyarországon. Újabb florisztikai adatok a Felsőnyirádi-erdőből. - Botanikai Közlemények 53: 31-33.

TímÁR G. (1995): A Vendvidék védett és veszélyeztetett növényei. - Vasi Szemle 49: 3-18. 
TRAXLER G. (1984): Neue Beiträge zur Flora des Burgenlandes I-II. - Burgenländische Heimatblätter 46: 15-28, 76-88.

VIDÉKI R. \& HuSZÁR H. (2002): A Kőszegi Alsó-rétek botanikai vizsgálata. - Praenorica Folia HistoricoNaturalia 6: 7-23.

Víg K., Merkl O., Nagy F., ÁdÁm L., Szalóki D, Podlussány A., Nádai L., Dankovics R. \& Vadász D. (2006): A kenyeri reptér - tervezett különleges természetmegőrzési területnek jelölt terület bogárfaunisztikai vizsgálata (Insecta: Coleoptera). - Praenorica Folia Historico-Naturalia 9: 123-169.

WAISBECKER A. (1882): Köszeg és vidékének edényes növényei. - Leintner N., Kőszeg, 47 pp.

WAISBECKER A. (1891): Kőszeg és vidékének edényes növényei 2. javított és bővített kiadás. - Kilián, Kőszeg, $80 \mathrm{pp}$.

WAISBECKER A. (1895): Beiträge zur Flora des Eisenburger Comitates. - Österreichische Botanische Zeitschrift 45: 109-111.

WAISBECKER A. (1908): Újabb adatok Vasvármegye flórájához. Neue beträge zur Flora des Eisenburger Comitates in West-Ungarn. - Magyar Botanikai Lapok 25: 14-22.

WALLNER I. (1903): Sopron környékén található virágos növények és edényes cryptogamok nevei és fajai. - Soproni Állami Föreáliskola Értesítője, 42 pp.

Beérkezett / received: 2015. 08. 22. • Elfogadva / accepted: 2015. 10.11. 